Journal for ImmunoTherapy of Cancer

\title{
A very long-acting IL-15: implications for the immunotherapy of cancer
}

\author{
John A Hangasky (D) , ${ }^{1}$ Wei Chen, ${ }^{2}$ Sigrid P Dubois, ${ }^{2}$ Anusara Daenthanasanmak, ${ }^{2}$ \\ Jürgen R Müller, ${ }^{2}$ Ralph Reid, ${ }^{1}$ Thomas A Waldmann (D) ,, Daniel V Santi ${ }^{1}$
}

To cite: Hangasky JA, Chen W, Dubois SP, et al. A very longacting IL-15: implications for the immunotherapy of cancer. Journal for ImmunoTherapy of Cancer 2022;10:e004104. doi:10.1136/jitc-2021-004104

- Additional supplemental material is published online only. To view, please visit the journal online (http://dx.doi.org/10. 1136/jitc-2021-004104).

TAW and DVS contributed equally.

WC, SPD and AD contributed equally.

Accepted 14 December 2021

Check for updates

(c) Author(s) (or their employer(s)) 2022. Re-use permitted under CC BY-NC. No commercial re-use. See rights and permissions. Published by BMJ.

${ }^{1}$ ProLynx Inc, San Francisco, California, USA

2Lymphoid Malignancies Branch, Center for Cancer Research, National Cancer Institute, Bethesda, Maryland, USA

Correspondence to

Dr Daniel V Santi;

Daniel.v.santi@prolynxinc.com

\section{ABSTRACT}

Background Interleukin-15 (IL-15) is an important cytokine necessary for proliferation and maintenance of natural killer (NK) and $\mathrm{CD}^{+} \mathrm{T}$ cells, and with great promise as an immuno-oncology therapeutic. However, IL-15 has a very short half-life and a single administration does not provide the sustained exposure required for optimal stimulation of target immune cells. The purpose of this work was to develop a very long-acting prodrug that would maintain IL-15 within a narrow therapeutic window for long periods - similar to a continuous infusion.

Methods We prepared and characterized hydrogel microspheres (MS) covalently attached to IL-15 (MS IL-15) by a releasable linker. The pharmacokinetics and pharmacodynamics of MS IL-15 were determined in C57BL/6J mice. The antitumor activity of MS IL-15 as a single agent, and in combination with a suitable therapeutic antibody, was tested in a $\mathrm{CD}^{+} \mathrm{T}$ cell-driven bilateral transgenic adenocarcinoma mouse prostate (TRAMP)-C2 model of prostatic cancer and a NK celldriven mouse xenograft model of human ATL (MET-1) murine model of adult T-cell leukemia.

Results On subcutaneous administration to mice, the cytokine released from the depot maintained a long halflife of about 168 hours over the first 5 days, followed by an abrupt decrease to about $\sim 30$ hours in accordance with the development of a cytokine sink. A single injection of MS IL-15 caused remarkably prolonged expansions of NK and ${ }_{\gamma} \delta \mathrm{T}$ cells for 2 weeks, and CD $44^{\mathrm{hi}} \mathrm{CD}^{+} \mathrm{T}$ cells for 4 weeks. In the NK cell-driven MET- 1 murine model of adult T-cell leukemia, single-agent MS IL-15 yg or anti-CCR4 provided modest increases in survival, but a combination-through antibody-depedent cellular cytotoxicity (ADCC) - significantly extended survival. In a $\mathrm{CD}^{+} \mathrm{T}$ cell-driven bilateral TRAMP-C2 model of prostatic cancer, single agent subcutaneous MS IL-15 or unilateral intratumoral agonistic anti-CD40 showed modest growth inhibition, but the combination exhibited potent, prolonged bilateral antitumor activity.

Conclusions Our results show MS IL-15 provides a very long-acting $\mathrm{IL}-15$ with low $\mathrm{C}_{\max }$ that elicits prolonged expansion of target immune cells and high anticancer activity, especially when administered in combination with a suitable immuno-oncology agent.

\section{INTRODUCTION}

Interleukin-15 (IL-15) is a $\sim 14 \mathrm{kDa}$ protein belonging to a family of interleukins that use a common cytokine-receptor $\gamma$-chain. IL-15 is essential for the proliferation, maintenance, and survival of natural killer (NK) and CD8 ${ }^{+}$ T cells, and recombinant human IL-15 (rhIL15 , hereafter referred to as IL-15) is of major interest as an immuno-oncology agent. ${ }^{1-5}$ This pleiotropic cytokine stimulates immune cell responses through the same dimeric IL-2R $\beta$ / $\gamma \mathrm{c}$ receptor complex as IL-2 (figure 1) but the two cytokines exhibit functionally distinct activities associated with their unique $\mathrm{R} \alpha$ subunits. ${ }^{6}$ IL-15 is expressed in association with its high-affinity IL-15R $\alpha$ receptor chain on the surface of monocytes and dendritic cells and is predominately trans-presented to target immune cells to form a high-affinity IL-15/IL-15R $\alpha /$ IL-2R $\beta / \gamma \mathrm{c}$ complex $^{7}{ }^{8}$; in addition, to a lesser extent free soluble IL-15 can act in cis on dimeric and trimeric receptors. IL-2 binds with moderate affinity to the same IL-2R $\beta / \gamma$ c receptor complex and with high affinity to the IL-2R $\alpha /$ IL-2R $\beta / \gamma c$ trimeric receptor found on regulatory $\mathrm{T}$ cells. Thus, both IL-15 and IL-2 bind to and stimulate $\mathrm{NK}$ and $\mathrm{CD}^{+} \mathrm{T}$ cells, but regulatory $\mathrm{T}$ cells are predominately stimulated by IL-2. Moreover, in contrast to IL-2, IL-15 inhibits activation-induced cells death, which leads to memory cell survival. ${ }^{9}$ Although IL-15 has modest anticancer activity as a single agent, it shows significant effects in combination with other immuno-oncology agents and it is in this setting that IL-15 is expected to be efficacious. $^{3}$

NK and memory T-cell proliferation requires IL-15 exposure at a level above a threshold concentration for a protracted period-a critical 'time-over-target' ${ }^{10-12}$ However, IL-15 has a short $\mathrm{t}_{1 / 2}$-only $\sim 2.5$ hours in humans - and the high dose of a single injection necessary to achieve adequate sustained exposure is accompanied by a high $\mathrm{C}_{\max }$ and associated toxicities. ${ }^{13}$ Hence, extensive efforts have been expended to develop potent, long-acting IL-15 receptor agonists in which a single dose maintains the agonist in a narrow therapeutic window for a long period. The most common approaches employed to 


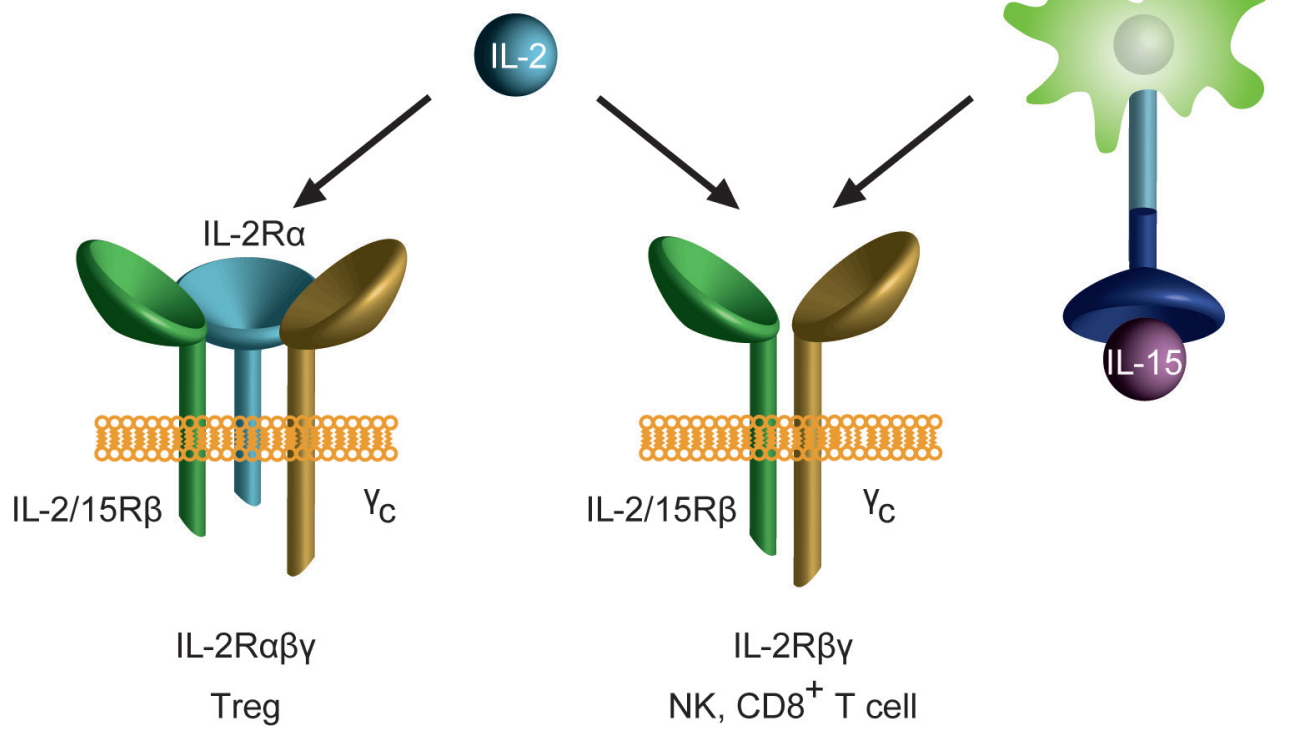

increase the $t_{1 / 2}$ of IL-15 involves increasing the molecular size to reduce the renal elimination rate and/or by targeting the neonatal $\mathrm{Fc}$ receptor $(\mathrm{FcRn})$. These include incorporation of part of the IL-15R $\alpha$ and/or attachment to polyethylene glycol (PEG), Fc, or serum albumin to the cytokine, and are exemplified by Alt-803 (IL-15 N72D/ IL-15R $\alpha$-Fc), hetIL-15 (IL-15/IL-15R $\alpha$ ), RLI (single chain fusion of IL-15 and IL-15R $\alpha_{\text {sushi }}$ ), and NKTR-255 (PEGylated IL-15) ${ }^{14}$ Enigmatically, although the half-life extension technologies used often lengthen the $t_{1 / 2}$ of a protein to a week or longer in humans, the IL-15 agonists studied have systemic elimination $\mathrm{t}_{1 / 2} \mathrm{~s}$ of not longer than 1 day and usually only several hours. ${ }^{1 / 2}$ Another approach to maintain a constant level of IL-15 for a prolonged period is continuous intravenous infusion (CIV). Here, 5 -day ${ }^{15}$ or 10-day ${ }^{16} \mathrm{CIV}$ of IL-15 showed remarkable increases of CD8 ${ }^{+} \mathrm{T}$ cells, NK cells, and CD56 ${ }^{\text {bright }} \mathrm{NK}$ cells. Regardless, CIV administration is an impractical route of administration, and it is desirable to have an effective IL-15 agonist possessing the convenience and acceptance of a single subcutaneous injection of once weekly or longer intervals.

We have developed a general approach for half-life extension of therapeutics in which the pharmacokinetics (PK) of the circulating drug can mimic a continuous infusion. As previously described, ${ }^{17} 18$ a drug is covalently tethered to a long-lived carrier by a linker that slowly cleaves by $\beta$-elimination to release the free drug (figure 2). The base-catalyzed first-order cleavage rate of the linker is controlled by the nature of an electronwithdrawing 'modulator' (Mod), which regulates the acidity of an adjacent carbon-hydrogen bond. These linkers are not affected by enzymes and are extraordinarily stable when stored at low $\mathrm{pH}$ and temperature. ${ }^{17} 19$ One carrier we use is a mesoporous tetra-PEG hydrogel. ${ }^{18} 20$ These hydrogels-fabricated as uniform $\sim 60 \mu \mathrm{m}$ microspheres (MS) ${ }^{20}$-are injected subcutaneously through a small-bore needle where they serve as a stationary, localized depot to slowly release the drug to the systemic circulation. We also incorporate slower cleaving $\beta$-eliminative linkers in crosslinks of these polymers, so gel degradation occurs in vivo after drug release. 1821

The primary objective of this work was to develop a very long-acting IL-15. First, we describe the synthesis and characterization of an MS IL-15 prodrug. Next, we describe the PK of the conjugate in mice, and show a very long half-life and low $\mathrm{C}_{\max }$ of the released cytokine. Then, we describe the remarkably long-lasting effects of subcutaneous MS IL-15 on the proliferation and expansion of $\mathrm{NK}$ and $\mathrm{CD}^{+} \mathrm{T}$ cells. Finally, we demonstrate potent antitumor activity of MS IL-15 in combination with anti-CCR4

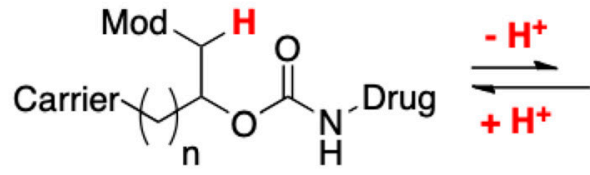

1<smiles>CCC(C)(CC)C(CC)(CC)OC(=O)Nc1ccccc1</smiles>

2

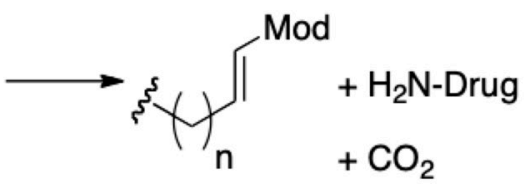

3

Figure $2 \beta$-Eliminative drug release. Mod, modulator. 
in the MET-1 model of adult T-cell leukemia (ATL), and in combination with intratumoral (IT) agonistic anti-CD40 in the bilateral TRAMP-C2 model of prostatic cancer.

\section{MATERIALS AND METHODS}

The following are materials and methods used in this work. Complete details of chemical syntheses and characterization, $\mathrm{PK}$ and pharmacodynamic (PD) experiments, and therapeutic studies are provided in online supplemental information.

\section{Materials}

IL-15 (>95\% pure) was provided by the National Cancer Institute. Receptor-linked interleukin-15 (RLI) was produced at ATUM (Newark, California) as reported. ${ }^{22}$ Mogamulizumab-kpkc (NDC code 42747-761-01) was obtained from the NIH Pharmacy. Anti-CD40 (\#BP0016-2) was obtained from BioXCell (Lebanon, New Hampshire). C57B/6J plasma was purchased from Innovative Research (Novi, Michigan). All other chemicals and reagents were purchased from commercial vendors unless otherwise stated.

\section{Preparation of MS IL-15}

As described, ${ }^{23}$ azido-linker-IL-15 was prepared by conjugating $\mathrm{N}_{3}-\mathrm{PEG}_{4}-$ Linker $\left(\mathrm{MeSO}_{2}\right)$-CHO to the $\mathrm{IL}-15$ via reductive alkylation using $\mathrm{NaCNBH}_{3}$. Excess reagents were removed using a PD-10 column (GE Healthcare). Then, the azido-linker-IL-15 was attached to BCNderivatized MS through strain promoted azide-alkyne cycloaddition. The unreacted BCN groups were capped with $\mathrm{N}_{3}-\mathrm{PEG}_{7}$ (Sigma-Aldrich). The MS IL-15 slurry was washed and equilibrated with $25 \mathrm{mM}$ citrate, $\mathrm{pH} 6.0,500$ $\mathrm{mM} \mathrm{NaCl}$, and $0.05 \%$ tween-20 containing $30 \mathrm{mM}$ Met as an anti-oxidant and stored at $4^{\circ} \mathrm{C}$.

\section{In vitro characterization of MS IL-15}

The release kinetics of MS IL-15 were determined under accelerated release conditions as previously described. ${ }^{1820}$ The purity of IL-15 on the MS was determined by monitoring the released proteins at $\mathrm{pH} 9.4,37^{\circ} \mathrm{C}$ using highperformance liquid chromatography (HPLC). The bioactivity of ${ }^{\alpha} \mathrm{N}$-aminopropyl-IL-15 (IL-15 $5_{\mathrm{AP}}$ ) was assessed using the U2OS cell-based assay kit for IL-2R $\beta \gamma$ binding (DiscoverX, Part \#93-0998E3CP5).

\section{Pharmacokinetics of MS IL-15 in immunocompetent mice}

Dosing solutions were prepared by diluting the MS IL-15 slurry in $25 \mathrm{mM} \mathrm{Na}$ citrate buffer $\mathrm{pH} 6.0$ containing 500 $\mathrm{mM} \mathrm{NaCl}, 0.05 \%$ tween-20, and $1.25 \%$ (w/v) hyaluronic acid. Syringes with fixed needles $(27 \mathrm{G})$ were backfilled with the MS IL-15 conjugate $(50 \mu \mathrm{g}$ IL-15, $100 \mu \mathrm{L})$. The contents of the syringes were administered subcutaneously to normal, male C57BL/6J mice or NOD scid gamma (NSG) mice. Blood samples were collected in EDTA collection tubes, containing HALT protease inhibitor, over a predefined time course from alternating groups of mice ( $n=3 /$ group). Plasma was prepared and stored at $-80^{\circ} \mathrm{C}$ until analysis. The rhIL-15 concentrations in serum were assessed using a hIL-15-specific ELISA (R\&D Systems, hIL-15 Quantikine) performed according to the manufacturer's instructions.

\section{Pharmacodynamics of MS IL15}

Normal, male C57BL/6J mice ( $\mathrm{n}=3-5 /$ group) received either a single injection of MS IL- $15_{50} \mathrm{\mu g}$ subcutaneously or one to five injections of rhIL-15 $(5-50 \mu \mathrm{g})$ intraperitoneally. On days $2,5,7,14,21$, and 28 , mice were bled or sacrificed. Blood, splenocytes, and lymph node lymphocytes were immunophenotyped to quantitate NK cells, $\mathrm{B}$ cells, $\mathrm{CD} 4^{+}, \mathrm{CD} 8^{+}, \mathrm{CD} 44^{\mathrm{hi}} \mathrm{CD} 8^{+}, \gamma \delta \mathrm{T}$ cells, and $\mathrm{Ki} 67^{+}$ cells. Untreated mice were used to determine baseline cell numbers.

\section{Flow cytometry}

Peripheral blood mononuclear cells (PBMCs) were prepared using ammonium-chloride-potassium (ACK) lysis buffer and incubated with a fixable viability dye to label dead cells. The FcR $\gamma \mathrm{II} / \mathrm{II}$ receptor was then blocked using CD16/32 (2.4G2) (BD Biosciences). PBMCs were surface stained using optimal $\mathrm{Ab}$ concentrations and fixed for intracellular staining following protocols from the eBioscience Foxp3/Transcription Factor Staining Buffer Set (online supplemental table S1). Stained single cell suspensions were analyzed on either FACScan (BD Biosciences) or Attune NxT flow cytometer (Thermofisher) and data were analyzed using FlowJo cytometry analysis software (TreeStar, Ashland, Oregon).

\section{TRAMP-C2 model}

The TRAMP-C2 cell line, derived from a prostate tumor of the TRAMP mouse, was administered to four groups of wild-type C57BL/6J mice on both flanks. Following reported methods ${ }^{24}$ when the tumors volumes reached $40-60 \mathrm{~mm}^{3}$, treatment began. Mice were treated with either empty MS, anti-CD40, MS ILL15 $5_{50 \mu g}$, or the combination of MS IL- $15_{50} \mathrm{pg}$ and anti-CD40. Measurements of the right and left tumors were obtained from caliper measurements. Kaplan-Meier mouse survival plots were generated based on the mouse survival, monitored based on humane end point criteria.

\section{MET-1 murine model of ATL}

The MET-1 cell line was established from the peripheral blood collected from a patient with acute ATL. ${ }^{25}$ The ATL leukemia model MET-1 was established by the intraperitoneal injection of $2 \times 10^{7}$ MET- 1 cells into severe combined immunodeficient/non-obese diabetic (SCID/ NOD) wild-type mice as described previously. ${ }^{25}{ }^{26}$ Treatment began when the sIL-2Ra levels were $>1000 \mathrm{pg} / \mathrm{mL}$ serum. MS IL- $15_{50}$ gg was administered to mice subcutaneously. On day 10 , sIL-2R $\alpha$ levels were quantitated using a human CD25/IL-2R $\alpha$ Quantikine ELISA kit (R\&D Systems, DR2A00) following manufacturer's instructions. Kaplan-Meier mouse survival plots were generated based on the survival of mice in each group. 


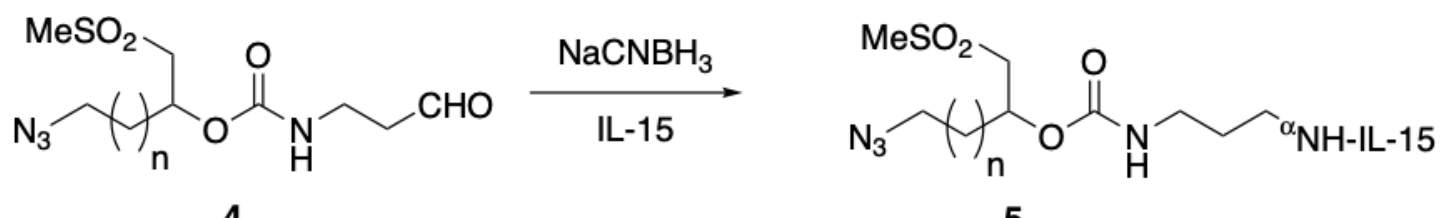

4

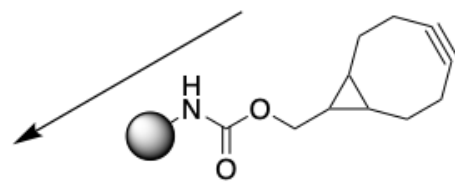

5
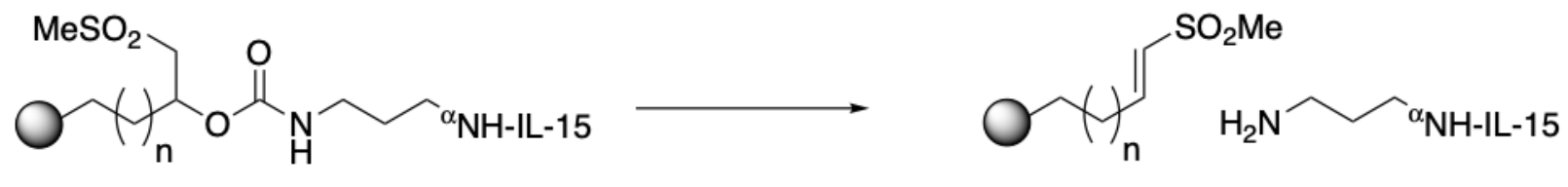

6

$\mathrm{IL}-15_{\mathrm{AP}}$

Figure 3 Synthesis of MS IL-15 and IL-15 AP release. IL, interleukin; IL-15 ${ }_{A P}{ }^{\alpha} \mathrm{N}$-aminopropyl-IL-15; MS, microspheres.

\section{Statistical analysis}

Statistical testing was performed using GraphPad Prism V.9. Values are presented as mean $\pm \mathrm{SD}$, unless otherwise stated, and are reported in the text and figure legends. In all cases, values of $\mathrm{p}<0.05$ were regarded as statistically significant.

\section{RESULTS}

\section{Preparation and characterization of MS IL-15}

We prepared the MS IL-15 conjugates by a reported method for site-specific attachment of macromolecular carriers to the N-terminus of proteins ${ }^{23}$ (figure 3). Amine-derivatized MS, prepared from 4-arm $\mathrm{PEG}_{20 \mathrm{kDa}}$ prepolymers and containing a $\beta$-eliminative linker in all crosslinks for programmed biodegradation, ${ }^{20}$ served as the macromolecular carrier. First, we determined the optimal ratio of $\mathrm{N}_{3}$-linker-aldehyde $4\left(\mathrm{Mod} \mathrm{MeSO}_{2}-\right)$ to rhIL-15 that gave the highest balanced yield of monoalkylated $\mathrm{N}_{3}$-linker-IL-15, 5 (online supplemental figure $\mathrm{S} 1$ ). A PEG-shift sodium dodecyl sulfate-polyacrylamide gel electrophoresis assay of the optimized reaction mixture ${ }^{23}$ showed $\sim 45 \%$ unreacted IL-15, 55\% IL-15 having one linker and $\leq 5 \%$ with more than one linker; thus, $\geq 90 \%$ of the product was the desired monoalkylated IL-15. Then, the $\mathrm{N}_{3}$-linker-IL-15, 5, was coupled to BCN-modified MS by strain-promoted alkyne-azide cycloaddition, and unreacted 5 and free IL-15 were washed from the particulate MS to give the MS IL- 15 containing $\sim 5 \mathrm{mg}$ IL- $15 / \mathrm{mL}$ gel slurry.

Base catalyzed $\beta$-elimination of the MS IL-15 resulted in complete release of $\mathrm{N}^{\alpha}$-amino-propyl IL-15 (IL-15 ${ }_{\mathrm{AP}}$ ) with $\mathrm{t}_{1 / 2} 1030$ hours, in agreement with previous results using the same linker. ${ }^{23}$ The purity of IL- $15_{\mathrm{AP}}$ on the MS IL-15 conjugate was assessed by HPLC quantitation of released proteins versus time at $\mathrm{pH}$ 9.4; when extrapolated to $\mathrm{t}=0$, $\geq 95 \%$ of the protein on MS analyzed as IL- $15_{\mathrm{AP}}$ (online supplemental figure S2). In accordance with the high stability of linkers at low $\mathrm{pH}$ and temperature, ${ }^{17} 19$ after 1 month of storage at $\mathrm{pH} 6.0,4^{\circ} \mathrm{C}$, the purity of IL- 15 on the
MS remained $>92 \%$ (online supplemental figure S2B). Finally, the half maximal effective concentration $\left(\mathrm{EC}_{50}\right)$ of IL- $15_{\mathrm{AP}}$ released from the MS IL- 15 at $\mathrm{pH} 7.4$ over 10 days was the same $(95 \% \mathrm{CI})$ as native IL-15 in both an IL-2R $\beta / \gamma_{c}$ dimerization cell-based assay and CTLL-2 cell proliferation assay, demonstrating that IL- $15_{\mathrm{AP}}$ released from MS is equipotent to native IL-15 (online supplemental figure S3).

\section{Stability of IL-15}

Successful use of MS IL-15 requires that the attached IL-15 be stable in the subcutaneous space and under storage conditions. Asn77 of IL-15 undergoes deamidation with $\mathrm{a} \mathrm{t}_{1 / 2}$ of $\sim 4$ days at $\mathrm{pH} 7.4,37^{\circ} \mathrm{C}$, but the IL-15(Asp77) product is equipotent in the CTLL-2 bioassay and $<5 \%$ additional degradation occurred over 8 days. ${ }^{27}{ }^{28}$ Here, when IL-15 was kept at $\mathrm{pH} 7.4,37^{\circ} \mathrm{C}$, for 10 days, there was no significant change in $\mathrm{EC}_{50}$ in cell-based IL-2R $\beta$ / $\gamma c$ dimerization or ELISA assays (online supplemental figure S4). At storage conditions at $\mathrm{pH} 6.0,4^{\circ} \mathrm{C}$, Asn 77 deamidation is very slow ${ }^{27}$ and we observed no significant change in the $\mathrm{EC}_{50}$ of IL-15 over 28 days using the cellbased assay (online supplemental figure S5). Hence, the IL-15 of MS IL-15 is sufficiently stable to withstand conditions expected in the subcutaneous space and for longterm storage.

\section{Pharmacokinetics of MS IL-15}

The concentration versus time plot of $\mathrm{IL}-15_{\mathrm{AP}}$ released from a single subcutaneous dose of MS containing $50 \mu \mathrm{g}$ IL-15, designated as MS IL- $15_{50} \mathrm{\mu g}$, in C $57 \mathrm{BL} / 6 \mathrm{~J}$ mice is shown in figure 4 . We chose a standard dose of MS IL$15_{50 \mu g}$ because it provides a plasma concentration in mice similar to the $\sim 200$ to $300 \mathrm{pM}$ effective plasma level attained in CIV IL-15 in monkeys ${ }^{29}$ and man. ${ }^{16}$ As shown, IL-15 ${ }_{\mathrm{AP}}$ released from MS IL-15 $5_{50 \mathrm{~g}}$ eliminates with $\mathrm{a} \mathrm{t}_{1 / 2}$ of $\sim 168$ hours over $\sim 120$ hours which then abruptly decreases to a $\mathrm{t}_{1 / 2} \sim 30$ hours, both significantly longer than other IL-15 agonists (table 1). When a second dose of MS IL- $15_{50 \mathrm{gg}}$ was administered on day 


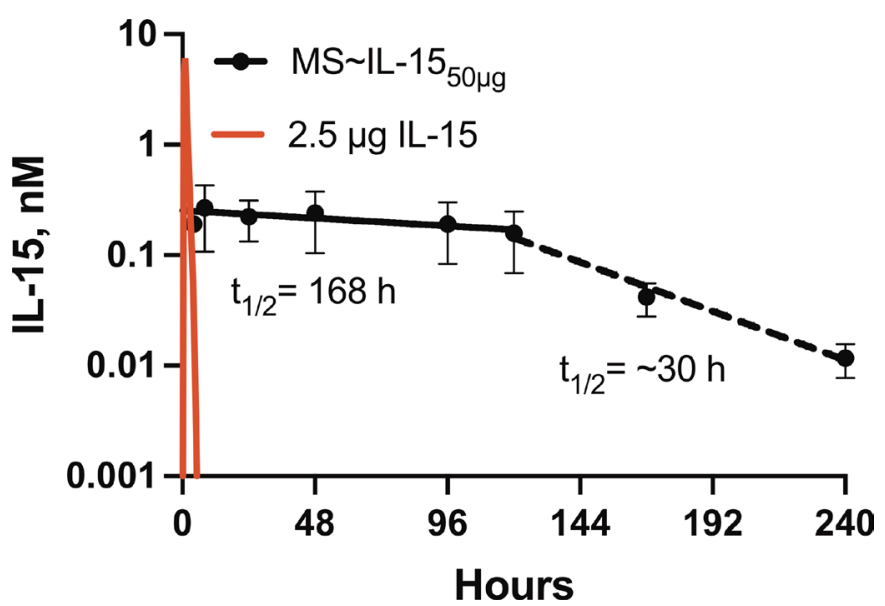

Figure $4 \mathrm{C}$ versus t plot of IL-15 , released from MS IL-15. Mice ( $\mathrm{n}=3$ /group) were administered MS IL-15 ${ }_{50 \mu \mathrm{g}}$ on day 0 (O). The red line depicts the $C$ versus $t$ of $2.5 \mu \mathrm{g} \mathrm{IL-15}$ administered intraperitoneally that has a $\mathrm{t}_{1 / 2} \sim 0.5$ hour. Points are mean $\pm \mathrm{SD}$. IL, interleukin; IL-15 ${ }_{\mathrm{AP}}{ }^{\alpha} \mathrm{N}$-aminopropyl-IL-15; MS, microspheres.

10 to mice previously treated with MS IL- $15_{50 \mu g}$, the $t_{1 / 2}$ was the $\sim 30$ hours observed in the second phase (online supplemental figure S6A). Using the area under the curve $(\mathrm{AUC})_{\infty}$ of IL- $15_{\mathrm{AP}}$ released from of MS IL- $15_{50 \mu \mathrm{g}}$ determined from $\mathrm{C}$ versus t plots $(\mathrm{n}=6)$, the reported clearance (CL) of $49 \mathrm{~mL} /$ hour for IL- $15^{30}$ and the eq. $\mathrm{F}=\mathrm{AUC}_{\infty} \bullet \mathrm{CL} /$ dose, we calculated a bioavailability of $66 \% \pm 12 \%$. With the NSG mouse-deficient in the yc receptor and mature immune cells - the $\mathrm{C}$ versus t plot after a single dose of MS IL- $15_{50 \mu \mathrm{g}}$ showed a single $\mathrm{t}_{1 / 2}$ of 200 hours over 24 days (online supplemental figure S6B). Hence, the unusual biphasic PK in normal mice is likely due to one or more classes of immune cells that are deficient in the NSG mouse.

Potential causes of the biphasic PK are (a) the formation of antidrug antibodies (ADAs) and/or (b) an IL-15induced 'cytokine sink' that increases with target immune cell proliferation and results in increased consumption/ CL of IL-15. ${ }^{141631}$ We considered ADAs improbable since identical biphasic $\mathrm{C}$ versus t plots were observed in each of 40 mice examined over the course of this work; such uniform occurrence and timing of ADA production is not an expected phenomenon. We also tested for the presence of ADAs using a bridging ELISA ${ }^{13}$ (online supplemental figure S7). Mice were injected with MS IL-15 ${ }_{\mu \mathrm{g}}$ and plasma was analyzed at day $10(\mathrm{n}=12)$; then, after a second injection of MS IL- $15_{50 \mu \mathrm{g}}$ at day 10 plasma was analyzed at day $17(\mathrm{n}=12)$. Both time points were sampled during the rapid CL phase when IL-15 was at a noninterfering $\sim 10 \mathrm{pM}$, so if ADAs contributed to CL, they should be present and detectable. All assayed samples were below the detectable level of $\sim 1.3 \mathrm{nM}$ of the control monoclonal antibody (mAb. Hence, it appears likely that the rapid CL phase is due to a cytokine sink that increases with proliferation of IL-15 target immune cells ${ }^{14}$; enigmatically, once formed at day 6 , the putative sink appears to be stable to at least day 17 .

\section{Pharmacodynamic effects of MS $\sim \mathrm{IL}-15_{50 \mu \mathrm{g}}$ and dose equivalent 5 $\mu \mathrm{g} \mathrm{IL-15}$ once a day $\times 5$}

With few exceptions, ${ }^{32}$ IL-15 PD effects on immune cell expansion in mice have been quantified by single measurements a short time after administration. While single measurements may suffice for agonists with short half-lives, they do not capture the duration or extent of response elicited by multiple administrations or an agonist with a long half-life. Also, they can be misleading when used to compare effects of different regimens or agonists in cell subtypes that reach maxima at different times. Therefore, initial experiments determined a time course for sampling and demonstrated that empty MS have no significant effect on immune cell expansion over 21-day period (online supplemental figure S8). Figure 5 shows NK and $\mathrm{CD} 8^{+} \mathrm{T}$ cells in spleen, lymph nodes, and PBMCs monitored over a 28-day period after a single injection of MS IL- $15_{50 \mu \mathrm{g}}$ and $5 \mu \mathrm{g}$ IL-15 once a day $\times 5$ in mice, and complete results are provided in online supplemental figure S9A,B. We estimated the amount of IL-15 ${ }_{\mathrm{AP}}$ released from MS IL-15 each day by the eq.

Table 1 Half-lives of IL-15 agonists in mice

\begin{tabular}{|c|c|c|c|}
\hline IL-15 agonist & Route of administration* & Mouse $t_{1 / 2}$ hour & Reference \\
\hline MS IL-15 & Subcutaneous & $168(30 \dagger)$ & This work \\
\hline $\mathrm{MS}_{\mathrm{GDM}} \sim \mathrm{IL}-15$ & Subcutaneous & 50 & This work \\
\hline IL-15 & Intraperitoneal & 0.50 & 31 \\
\hline RLI (IL-15-IL-15R $\left.\alpha_{\text {sushi }}\right)$ & Intraperitoneal & 3 & 35 \\
\hline ALT-803 (IL-15 N72D/IL-15R $\alpha-F c)$ & Intravenous and subcutaneous & 7.5 & 54 \\
\hline NKTR-255 (PEG-IL-15) & Intravenous & 14 & 32 \\
\hline
\end{tabular}

${ }^{*}$ Not all routes of administration have been reported in mice.

†Second phase of $C$ versus t plot.

IL, interleukin; MS, microspheres. 
Spleen
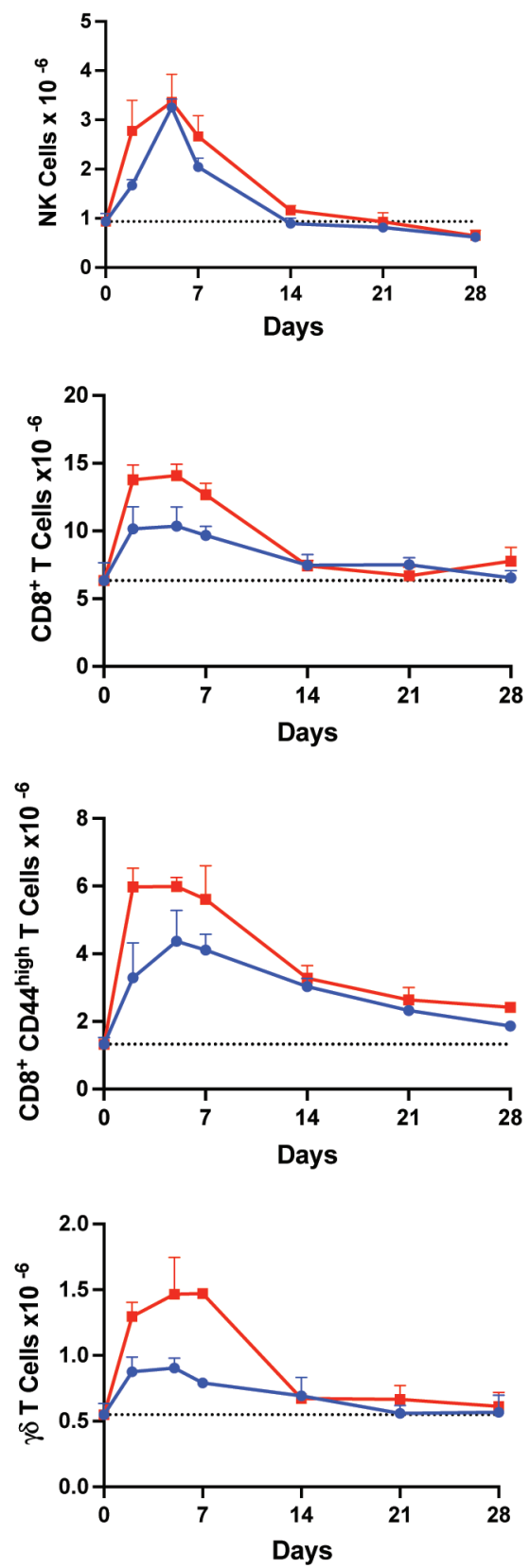

Lymph Nodes
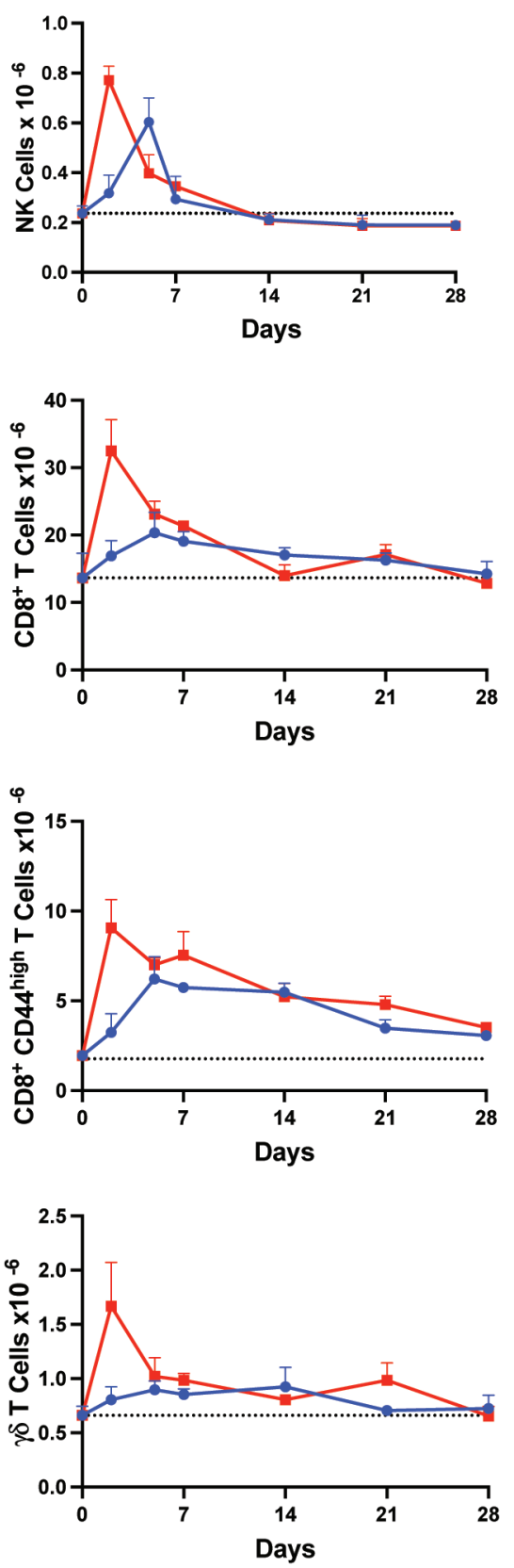

PBMCs
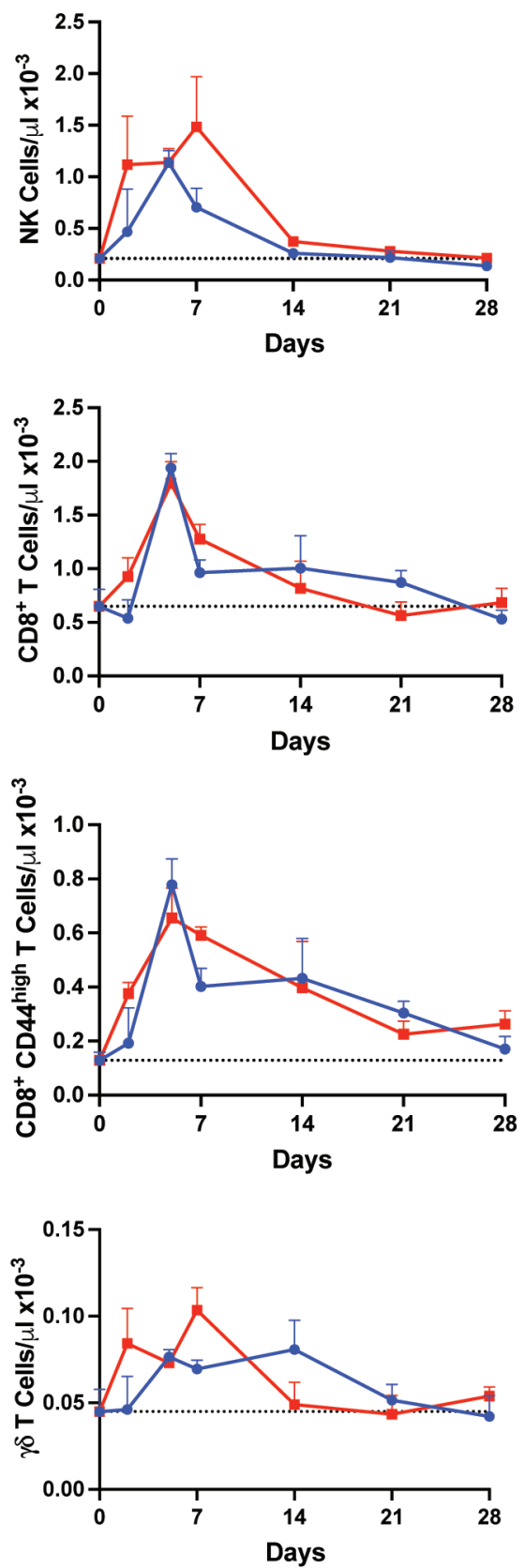

Figure 5 Immune cell expansion by MS IL- $15_{50 \mu \mathrm{g}}$ over 28 days. Enumeration of NK, CD $8^{+}, \mathrm{CD} 44^{\text {hi }} \mathrm{CD} 8^{+}$, and $\gamma \delta \mathrm{T}$ cells at $0,2,5,7,14,21$, and 28 days in the spleen, lymph nodes, and PBMCs of mice ( $\mathrm{n}=3 /$ point/group) treated with subcutaneous MS IL-15 $5_{50 \mu g}(\cdot)$ or intraperitoneal $5 \mu \mathrm{g} \mathrm{IL}-15$ once a day $\times 5(\boldsymbol{)})$. The dotted line represents the mean value of the pretreatment controls $(n=5)$. PBMCs were quantified using complete blood count. Points are mean \pm SD. IL, interleukin; MS, microspheres; NK, natural killer; PBMC, peripheral blood mononuclear cells.

$\mathrm{d}(\mathrm{n})=\mathrm{D} \times \mathrm{r}^{\mathrm{n}-1}(1-\mathrm{r})$, where $\mathrm{D}$ is the initial amount of IL-15 in the depot and $\mathrm{r}=-(24$ hours $) \times \ln 2 / \mathrm{t}_{1 / 2}$. In the present case, after injection of MS IL-15 $5_{50}$ using a release $\mathrm{t}_{1 / 2}$ of 168 hours, the calculated IL- $15_{\mathrm{AP}}$ released over day 1 is $4.7 \mu \mathrm{g}$, and on day 5 is $3.2 \mu \mathrm{g}$, giving an average IL-15 $5_{\mathrm{AP}}$ released over 5 days of $\sim 4 \mu \mathrm{g} /$ day.

For analyses of PD effects from cell number versus time plots (figure 5), a horizontal line was created from the pretreatment control value extending to the end of the 28-day study period. The duration of expansion was estimated as the closest measured time point to which the experimental data intersected the control horizontal line. The extent of cell expansion was estimated as the AUC over 28 days $\left(\mathrm{AUC}_{28 \mathrm{~d}}\right)$ between the horizontal control and the experimental line. Table 2 tabulates the values for duration and $\mathrm{AUC}_{2 \mathrm{~d}_{\mathrm{d}}}$ from figure 5 and online supplemental figure S9A. When preferred, the fold increase of cell expansion can be estimated as the experimental $\mathrm{AUC}_{28 \mathrm{~d}} /$ control $\mathrm{AUC}_{28 \mathrm{~d}}$ over the time of interest.

Several features of the AUC approach to measure total cell expansion are worthy of note. First, the proliferation $\mathrm{AUC}_{28 \mathrm{~d}}$ values are deceptively lower than conventionally 
Table 2 Duration of immune cell expansion and $\mathrm{AUC}_{28 \mathrm{~d}}$ in PBMCs, lymph nodes, and spleen

\begin{tabular}{|c|c|c|c|c|c|c|}
\hline \multirow[b]{2}{*}{ Marker } & \multirow[b]{2}{*}{ Tissue } & \multirow{2}{*}{$\begin{array}{l}\text { Predose control, cells } \\
\text { Mean } \pm \text { SD }^{*}\end{array}$} & \multirow{2}{*}{$\begin{array}{l}\text { Duration, day } \\
\text { IL-15 } \\
5 \mu g \text { once a } \\
\text { day } \times 5\end{array}$} & \multirow[b]{2}{*}{ MS IL-15 ${ }_{50 \mu g}$} & \multicolumn{2}{|c|}{ AUC, cells* day† } \\
\hline & & & & & $\begin{array}{l}\text { IL-15 } \\
5 \mu g \text { once a } \\
\text { day } \times 5\end{array}$ & MS IL-15 ${ }_{50 \mu \mathrm{g}}$ \\
\hline \multirow[t]{3}{*}{ NK1.1 $1^{+}$} & Spleen & $0.93 \pm 0.16$ & 14 & 14 & 10 & 19 \\
\hline & $\ln$ & $0.24 \pm 0.03$ & 14 & 14 & 0.71 & 1.5 \\
\hline & PBMC & $0.21 \pm 0.04$ & 14 & 14 & 5.4 & 12 \\
\hline \multirow[t]{3}{*}{$\mathrm{CD}^{+}$} & Spleen & $6.34 \pm 1.32$ & 14 & 14 & 51 & 82 \\
\hline & $\ln$ & $13.6 \pm 3.67$ & 14 & 14 & 94 & 130 \\
\hline & PBMC & $0.65 \pm 0.16$ & 21 & 21 & 8.0 & 7.1 \\
\hline \multirow[t]{3}{*}{$\mathrm{CD} 44^{\text {hi }} \mathrm{CD} 8^{+}$} & Spleen & $1.32 \pm 0.20$ & 28 & 28 & 46 & 69 \\
\hline & $\ln$ & $1.95 \pm 1.85$ & 28 & 28 & 70 & 104 \\
\hline & PBMC & $0.13 \pm 0.03$ & 28 & 28 & 6.5 & 7.0 \\
\hline \multirow[t]{3}{*}{$\mathrm{TCRy}^{+} \delta^{+}$} & Spleen & $0.55 \pm 0.09$ & 14 & 14 & 3.9 & 10 \\
\hline & $\ln$ & $0.66 \pm 0.08$ & 14 & 14 & 4.2 & 8.1 \\
\hline & PBMC & $0.04 \pm 0.01$ & 21 & 14 & 0.48 & 0.48 \\
\hline \multirow[t]{3}{*}{$\mathrm{Ki} 67^{+} \mathrm{NK} 1.1^{+}$} & Spleen & $0.14 \pm 0.05$ & 7 & 7 & 6.8 & 6.0 \\
\hline & In & $0.05 \pm 0.01$ & 7 & 7 & 1.1 & 1.5 \\
\hline & PBMC & $0.03 \pm 0.01$ & 14 & 14 & 2.3 & 2.5 \\
\hline \multirow[t]{3}{*}{$\mathrm{Ki} 7^{+} \mathrm{CD} 44^{\mathrm{hi}} \mathrm{CD} 8^{+}$} & Spleen & $0.47 \pm 0.16$ & 7 & 7 & 15 & 18 \\
\hline & $\ln$ & $0.65 \pm 0.21$ & 7 & 7 & 16 & 26 \\
\hline & PBMC & $0.03 \pm 0.01$ & 21 & 14 & 1.6 & 1.1 \\
\hline \multirow[t]{3}{*}{$\mathrm{Ki} 7^{+} \mathrm{TCRy}^{+} \delta^{+}$} & Spleen & $0.26 \pm 0.05$ & 14 & 14 & 3.5 & 8.6 \\
\hline & In & $0.36 \pm 0.07$ & 14 & 14 & 2.3 & 6.1 \\
\hline & PBMC & $0.020 \pm 0.005$ & 21 & 21 & 0.54 & 0.6 \\
\hline
\end{tabular}

${ }^{*}$ Control values are cells $\times 10^{-6}$ for spleen and lymph nodes $(\mathrm{In})$, and cells $/ \mu \mathrm{L} \times 10^{-3}$ for PBMCs.

†AUC values are cells $\times 10^{-6} \times$ day for spleen and $\mathrm{In}$, and cells $/ \mu \mathrm{L} \times 10^{-3} \times$ day for PBMCs.

AUC, area under the curve; IL, interleukin; MS, microspheres; PBMC, peripheral blood mononuclear cell.

reported because the $\mathrm{AUC}_{28 \mathrm{~d}}$ of parental cells includes the entire contraction phase; over the period of proliferation, the per cent Ki67 $7^{+}$of NK and $\mathrm{CD} 44^{\text {hi }} \mathrm{CD}^{+} \mathrm{T}$ cells were $70 \%-90 \%$ of the parent (online supplemental figure $\mathrm{S} 9 \mathrm{~A}$ ). Second, $\mathrm{AUC}_{28 \mathrm{~d}}$ of long-lived subsets, such as $\mathrm{CD} 44^{\text {hi }} \mathrm{CD}^{+} \mathrm{T}$ cells, may be deceptively high because the contraction phase may be longer than that of the parent. Third, with exception of NK cells, the $\mathrm{AUC}_{28 \mathrm{~d}}$ of target immune cell proliferation and expansion in PBMCs correlated with those from spleen and lymph nodes with $\mathrm{R}=99.3 \%$ and $98.8 \%$, respectively. $\mathrm{AUC}_{28 \mathrm{~d}}$ of NK cells in PBMCs were $\sim 10$-fold higher than expected compared with spleen and lymph nodes, which reduced the correlation; interestingly, NTKR-255 also shows very high expansion of NK cells in peripheral blood. ${ }^{32}$ Therefore, T cell expansion in mouse PBMCs can be legitimately used as surrogates to avoid sacrificing mice and performing numerous surgical procedures.

The duration of immune cell expansion of $5 \mu \mathrm{g}$ IL-15 once a day $\times 5$ vs MS $\sim \mathrm{IL}-15_{50}$ ig in spleen, lymph nodes, and PBMCs are all quite similar, showing $~ 14$ days for NK, $\mathrm{CD} 8^{+}$, and $\gamma \delta \mathrm{T}$ cells, and $\sim 28$ days for $\mathrm{CD} 44^{\mathrm{hi}} \mathrm{CD} 8^{+} \mathrm{T}$ cells.
As measured by $\mathrm{Ki} 67^{+}$, proliferation of $\mathrm{NK}, \mathrm{CD}^{+}$, and $\mathrm{CD} 44^{\text {hi }} \mathrm{CD}^{+} \mathrm{T}$ cells in all tissues usually peaks at $\sim 2$ days then drops to control by 7 days, although proliferation of $\gamma \delta \mathrm{T}$ cells reaches control levels at 14 days (online supplemental figure S9A). As expected, proliferation of $\mathrm{CD} 44^{\text {low }}{ }^{\mathrm{CD}} 8^{+}$-naïve $\mathrm{T}$ cells, $\mathrm{B}$ cells, and $\mathrm{CD} 4^{+} \mathrm{T}$ cells were not significant. On average, the $\mathrm{AUC}_{28 \mathrm{~d}}$ of immune cell proliferation and expansion for MS IL- $15_{50 \mathrm{\mu g}}$ is $\sim 150 \%$ of that for $5 \mu \mathrm{g}$ IL-15once a day $\times 5$.

Frutoso $e t a l^{33}$ observed hyporesponsiveness of NK cells but not $\mathrm{CD} 8^{+} \mathrm{T}$ cells after a second injection of IL-15, RLI, or RLI-Fc. On a second injection of MS IL- $15_{50}$ g 28 days after the first, we also observed low (40\%) proliferation of NK cells. CD8 ${ }^{+} \mathrm{T}$ cells were not affected when measured at a single time 2 days postadministration as reported, ${ }^{33}$ but the $\mathrm{AUC}_{28 \mathrm{~d}}$ of $\mathrm{CD}^{+} \mathrm{T}$ cells was attenuated by about $50 \%$.

\section{PD effects of single and sequential doses of IL-15 and super- agonist RLI}

We determined the PD effects in PBMCs after single doses of 5-50 $\mathrm{kg}$ IL-15 (figure 6 and online supplemental 
A

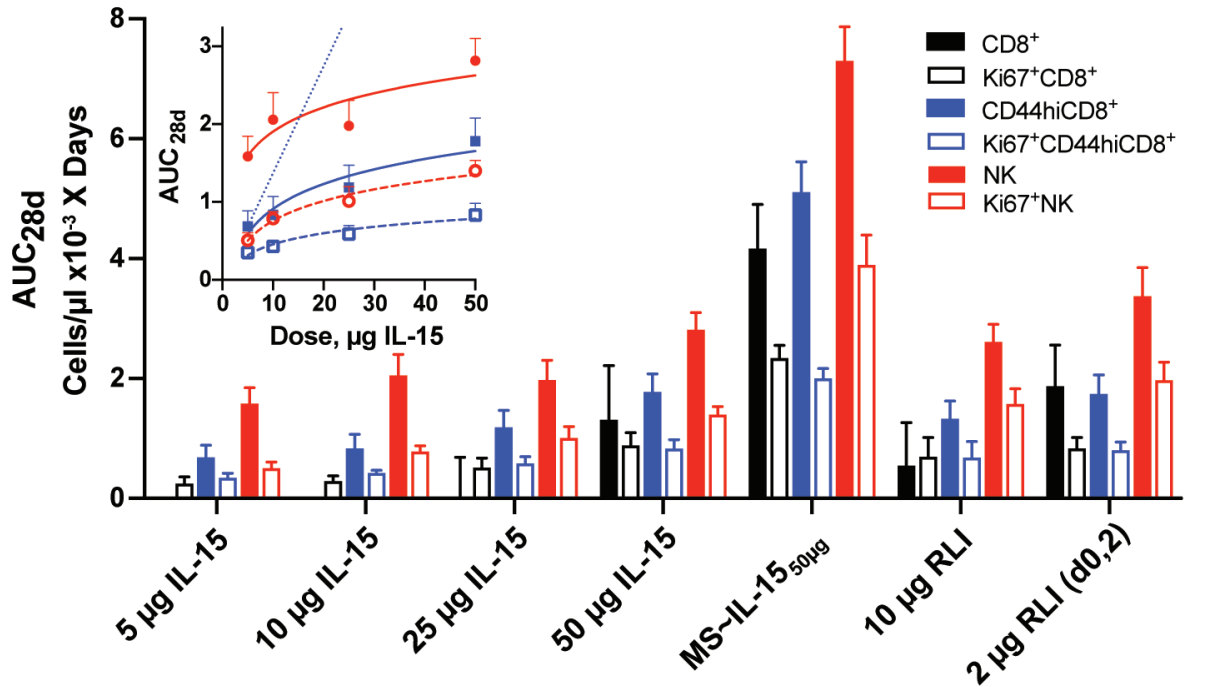

B

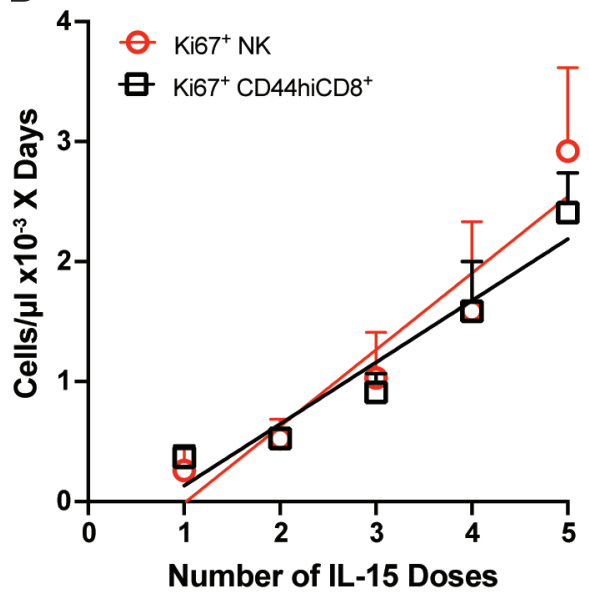

Figure 6 PD effects of single and sequential doses of IL-15 and the super-agonist RLI in PBMCs. (A) AUC ${ }_{28 d}$ for PD effect on target immune cells. Mice ( $n=4-5 /$ group) were administered single intraperitoneal doses of 5-50 $\mu \mathrm{g}$ IL-15, $10 \mu \mathrm{gLI}$, MS IL-15 $5_{50}$ ${ }_{\mu \mathrm{g}}$, or two doses of $2 \mu \mathrm{g} \mathrm{RLI}$ separated by 48 hours. PBMCs were collected over 28 days, and target immune cells analyzed

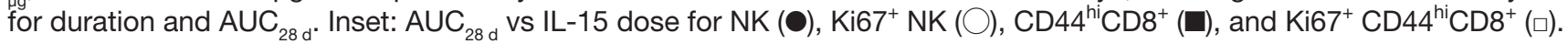
Data points are fitted to the logarithmic equation derived in SI. Here, the relative fold-change in time-over-target with an X-fold increase in dose $=1+\ln (\mathrm{X}) / \ln \left(\right.$ dose $\left._{1} / \mathrm{C}_{\min } \mathrm{V}_{\mathrm{d}}\right)$. The dotted line shows the trace for the $\mathrm{CD} 44^{\mathrm{hi}} \mathrm{CD} 8^{+} \mathrm{T}$ cell dose response when the response between 0 and $5 \mu \mathrm{g} \mathrm{IL-15}$ is used to define a linear slope. (B) PD effects of IL-15 after subcutaneous administration of $5 \mu \mathrm{g}$ to mice ( $\mathrm{n}=5 /$ group) on d0, then sequentially each day on d0-1, d1-2, d1-3, and d1-4. Analysis of $\mathrm{AUC}_{28 \mathrm{~d}}$ of Ki67 $7^{+}$ proliferating NK and CD44hi ${ }^{\text {h }} 8^{+}$T cells in PMBCs began on d0. Cell numbers were directly measured using an Attune NxT. Data show the mean $\pm S D$ of the $A \cup C_{28 \mathrm{~d}}$ for individual mice. AUC, area under the curve; IL, interleukin; MS, microspheres; NK, natural killer; PBMC, peripheral blood mononuclear cells; PD, pharmacodynamic.

figure S10). As shown in figure $6 \mathrm{~A}$, incremental doses of IL-15 caused incremental proliferation and expansion of target effector cells, but never to the extent of MS IL$15_{50 \mathrm{\mu g}}$. The $25 \mu \mathrm{g}$ dose of IL-15 is dose-equivalent to the $\mathrm{IL}-15_{\mathrm{AP}}$ released from MS IL- $15_{50 \mathrm{\mu g}}$ over 1 week, and the $50 \mu \mathrm{g}$ supra-high dose is equivalent to the total amount of IL-15 on MS IL- $15_{50} \mathrm{\mu g}$. In all cases, the PD responses of the single doses examined are much lower than the longacting MS IL-15 $5_{50 \mu \mathrm{g}}$.

The magnitude of the PD effect by an IL-15 agonist depends on a sufficient level of target engagement for a sufficient period of time, ${ }^{10-12}$ and wasted cytokine excess over receptor saturation increases $\mathrm{C}_{\max }$ but not signal intensity. As dose is increased, $\mathrm{C}_{\max }$ increases linearly whereas the time during which receptors are effectively saturated increases logarithmically (online supplemental section XII). Figure $6 \mathrm{~A}$, inset, shows that $\mathrm{AUC}_{28 \mathrm{~d}}$ of proliferation and expansion of immune cells versus IL-15 concentrations fit very well to a logarithmic relationship; in contrast, as illustrated for $\mathrm{CD} 44^{\mathrm{hi}} \mathrm{CD} 8^{+} \mathrm{T}$ cells, when the response between 0 and $5 \mu \mathrm{g}$ IL-15 is used to define a linear slope the fit is very poor. Hence, the observed PD effects of single varying doses of IL-15 are not correlated with $\mathrm{C}_{\max }$, but rather with the time receptors are occupied with sufficient IL-15 to expand immune cells.

We likewise inquired whether the high immune cell expansion after five daily doses of $5 \mu \mathrm{g}$ IL-15 occurred abruptly during the study period, or increased steadily with repeated doses. Mice were administered doses of
$5 \mu \mathrm{g}$ IL-15 for 1-5 successive days (online supplemental figure S11). Here, the $\mathrm{AUC}_{28 \mathrm{~d}}$ of proliferating $\mathrm{NK}$ and $\mathrm{CD} 44^{\text {hi }} \mathrm{CD}^{+} \mathrm{T}$ cells were linear $\left(\mathrm{R}^{2}=0.93\right)$ with the frequency of doses (figure 6B), as expected if each dose increased the time of exposure over some adequate target concentration. Taken together, the results indicate that optimal time-over-target cannot be achieved by single doses of different IL-15 quantities but can by multiple sequential doses of IL-15 or by a single administration of the long-acting MS IL- $15_{50 \mathrm{\mu g}}$.

We also examined the PD effects of the super-agonist RLI, a single chain fusion of IL-15, and the 77 aa IL-15R $\alpha$ sushi connected by a 20 -amino acid linker. As an IL-15R $\alpha$-independent agonist, RLI binds with $\sim 100$-fold higher affinity to the intermediate affinity IL-2R $\beta / \gamma c$ than IL-15 $5^{22} 34$ and has $\sim 6$-fold longer $\mathrm{t}_{1 / 2}$ in mice (table 1 ). ${ }^{35}$ As shown in figure $6 \mathrm{~A}, 10 \mu \mathrm{g}$ of RLI-equimolar to $6 \mu \mathrm{g}$ IL-15-produces a PD effect $>25 \mu \mathrm{g}$ IL-15, and two doses of only $2 \mu \mathrm{g}$ RLI separated by 2 days produces expansions superior to $10 \mu \mathrm{g}$ of RLI or $50 \mu \mathrm{g}$ IL-15. As with IL-15, the duration of receptor occupancy by RLI appears to play a more important role than dose intensity.

\section{MS IL-15 with an alternative linker and in vivo release rate}

In early experiments, we also prepared and partially characterized an MS IL-15 with the same $\mathrm{MeSO}_{2}$ modulator as in MS IL-15 placed on a gem-dimethyl substituted linker ${ }^{36}$ designated $\mathrm{MS}_{\mathrm{GDM}} \sim \mathrm{IL}-15$. The in vitro release $\mathrm{t}_{1 / 2}$ extrapolated to $\mathrm{pH} 7.4,37^{\circ} \mathrm{C}$ was 1000 hours, close 
to that of MS IL-15. However, in C57BL/6J mice the $\mathrm{t}_{1 / 2}$ of released IL-15 $5_{\mathrm{AP}}$ was 50 hours-still longer than any reported IL-15 agonist-but showed no second phase of CL. As calculated above for MS IL- $15_{50 \mu \mathrm{g}}$, we estimated the IL-15 ${ }_{\mathrm{AP}}$ released from $\mathrm{MS}_{\mathrm{GDM}} \sim \mathrm{IL}-15_{50}$ g over day 5 to be an average of $\sim 8 \mu \mathrm{g} /$ day. When $\mathrm{MS}_{\mathrm{GDM}} \sim \mathrm{IL}-15_{50 \mu \mathrm{g}}$ was injected in mice, analysis of duration and $\mathrm{AUC}_{28 \mathrm{~d}}$ of immune cell expansion was very similar, if not identical, to MS IL- $15_{50}$ ${ }_{\mu g}$ (online supplemental figure S12 and table S2); thus, it appears that a $\mathrm{t}_{1 / 2}$ of $50 \mathrm{hr}$ provides sufficient exposure to achieve optimal PD effects. Regardless, the present work focused on studies of MS IL-15 because the longer $t_{1 / 2}$ of released IL- $15_{\mathrm{AP}}$ over 5 days more resembled that of the target 5-day CIV of IL-15.

\section{Tolerability and safety of MS IL-15}

Toxicity and injection site reactions of subcutaneously administered $\mathrm{MS}_{\mathrm{GDM}} \sim \mathrm{IL}-15$ were assessed in mice. A complete summary of the study is provided in SI. Briefly, male C57BL/6J mice ( $\mathrm{n}=6$ /group) were administered $0.1 \mathrm{~mL}$ of blank MS, MS $\mathrm{GDM} \sim \mathrm{IL}-15_{150 \mu \mathrm{gg}}$, or $\mathrm{MS}_{\mathrm{GDM}} \sim \mathrm{IL}-15_{500 \mu \mathrm{g}}$ on days 1 and 15 via subcutaneous injections and animals were observed for 28 days. There were no IL-15-related clinical pathologies, organ weight abnormalities, macroscopic findings, bodyweight changes, or dose-dependent microscopic differences between $\mathrm{MS}_{\mathrm{GDM}} \sim \mathrm{IL}-15_{150 \mu g}$ and $\mathrm{MS}_{\mathrm{GDM}} \sim \mathrm{IL}-15_{500 \mu \mathrm{g}}$. Slight injection site swelling and minimal to moderate subcutaneous granulomatous inflammation was observed in all groups and there was a single occurrence of mild myofiber degeneration/ regeneration with $\mathrm{MS}_{\mathrm{GDM}} \sim \mathrm{IL}-15_{150 \mu \mathrm{g}}$. Hence, $\mathrm{MS}_{\mathrm{GDM}} \sim \mathrm{IL}-15$ administered day 1 and day 15 containing 150 or $500 \mu \mathrm{g}$ IL-15/animal/injection-releasing 6-fold to 20-fold more IL-15 than the standard single dose of MS IL- $15_{50 \mu \mathrm{g}}$ used in this study-was generally well tolerated by mice.

\section{Effect of MS IL-15 and agonistic anti-CD40 on the TRAMP-C2 prostatic cancer model}

In a previous study, a combination of IL-15, systemically administered at $2.5 \mu \mathrm{g} /$ mouse 5 days/week $\times 2$, and antiCD40 showed high synergistic antitumor activity in the primarily $\mathrm{CD}^{+} \mathrm{T}$ cell-driven murine TRAMP-C2 prostatic cancer model. ${ }^{24}$ Figure 7 shows the effects of subcutaneously administered IL-15 (figure 7A) or MS IL-15 (figure 7B) and IT administered anti-CD40 agonist in a bilateral syngeneic murine TRAMP-C2 model (Chen et al 2021, submitted). Here, the right tumor in each animal was injected with anti-CD40, and animals received ten intraperitoneal doses of $2.5 \mu \mathrm{g}$ IL-15 over 14 days or a single subcutaneous dose of MS IL-15 $5_{50}$ g . The combination of MS IL-15

\section{Right \\ i.t. Anti-CD40}

A
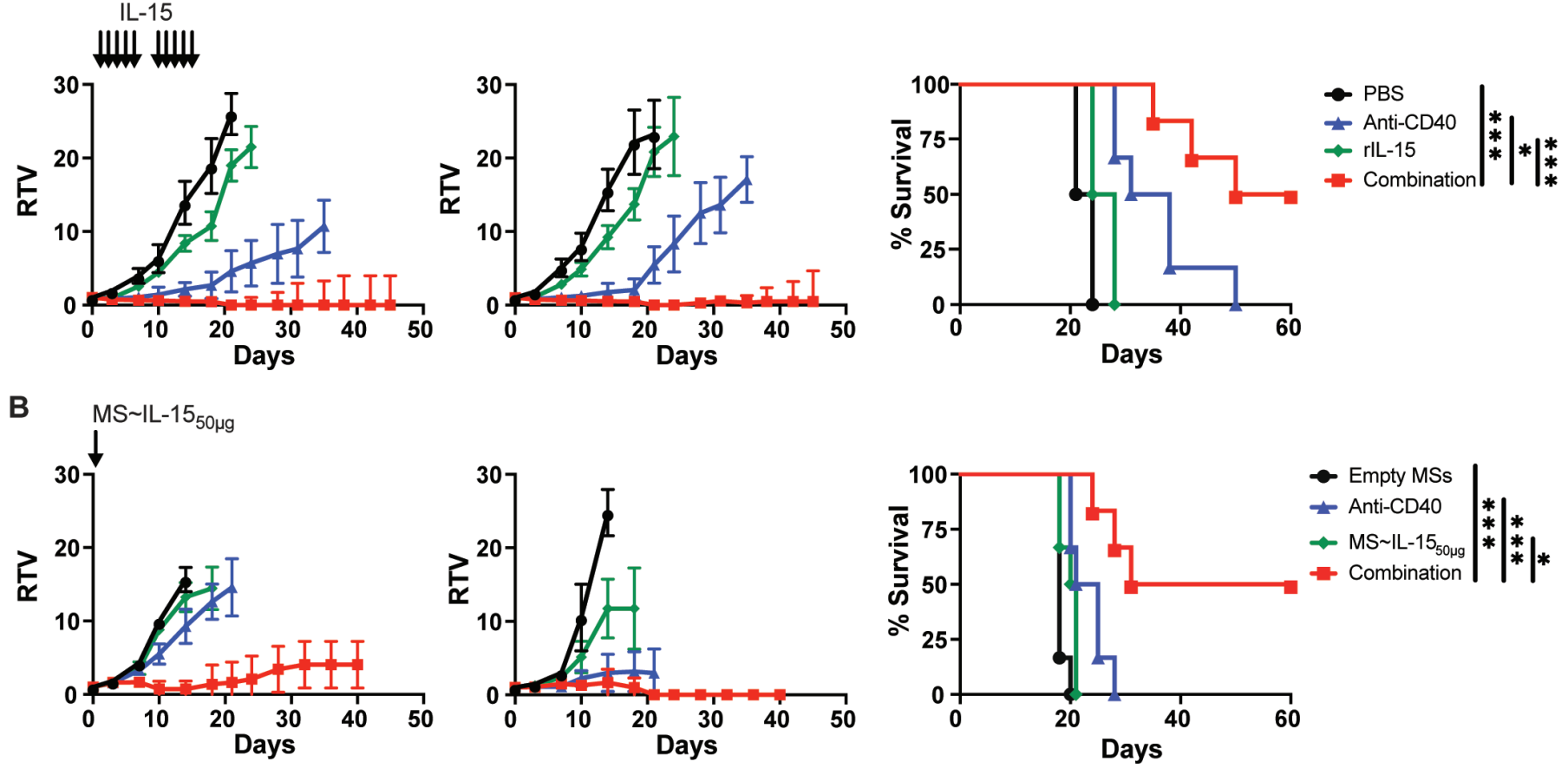

Figure 7 Antitumor effects of IL-15 and MS IL-15 in the TRAMP-C2 prostate tumor model. (A) RTV of C57BL/6J mice ( $\mathrm{n}=6$ / group) bearing TRAMP-C2 tumors on both flanks were treated with intraperitoneal $2.5 \mu \mathrm{g}$ IL-15 (days 1-5, 8-13), IT anti-CD40 $\mathrm{mAb}(20 \mu \mathrm{g} / 10 \mu \mathrm{L}$ on days $0,3,7$, and 10$)$ in the right-flank tumor or the combination of IL-15 plus anti-CD40; the KaplanMeier plot shows per cent of surviving mice. The control group was injected with PBS. (B) Same as top panel except using a single dose of subcutaneous MS IL-15 ${ }_{50 \mu \mathrm{g}}$ instead of multiple doses of IL-15. The control group was injected subcutaneously with empty MS. Data shown as relative median tumor volume \pm SE of the median. Two-way analysis of variance and log-rank (Mantel-Cox) tests were used to determine statistical differences. ${ }^{*} \mathrm{P}<0.05,{ }^{\star \star \star} \mathrm{p}<0.001$. IL, interleukin; IT, intratumoral; MS, microspheres; mAb, monoclonal antibody; PBS, phosphate-buffered saline; RTV, relative median tumor volume. 
and anti-CD40 resulted in significant expansion in the absolute number of peripheral $\mathrm{CD} 8^{+} \mathrm{T}$ cells, $\mathrm{CD} 44^{\text {hi }} \mathrm{CD} 8^{+}$ $\mathrm{T}$ cells, and tumor-specific tetramer ${ }^{+} \mathrm{CD} 8^{+}$cells compared with either monotherapy (online supplemental figure S13). Growth of both tumors in mice injected with single agent anti-CD40, IL-15, or MS IL-15 $5_{50}$ pg showed modest tumor growth inhibition. However, growth of tumors in mice receiving both unilateral IT anti-CD40 and systemic IL-15 or MS IL-15 $5_{50 \mathrm{\mu g}}$ were suppressed for long periods. As shown in figure $7 \mathrm{~B}$, none of the mice in the single agent MS IL- $15_{50}$ or anti-CD40 groups survived, whereas $50 \%$ of the mice in the MS IL- $15_{50} \mathrm{pg} /$ anti-CD40 combination group were alive at day 60 , all being tumor free. Hence, the combination of systemic MS IL-15 $5_{50 \mathrm{\mu g}}$ and unilateral IT anti-CD40 produce a potent effect on the tumor injected with anti-CD40 as well as the non-injected tumor.
Effect of MS IL-15 and anti-CCR4 (mogamulizumab) on the MET-1 murine model of ATL)

It has been reported that IL-15 caused a NK cell-driven prolongation of survival of MET-1 tumor-bearing mice and thereby increased efficacy of anticancer mAbs through ADCC. ${ }^{26}$ Since the CC-chemokine receptor CCR4 is expressed on the surface of leukemic cells in most ATL cases, ${ }^{37}$ the MET-1 ATL model in NOD/SCID mice that lack $\mathrm{T}$ and $\mathrm{B}$ cells ${ }^{25}$ was used to test MS IL-15 in combination with anti-CCR4. After intraperitoneal injection of MET-1 cells when serum-soluble human IL-2R $\alpha$ - a surrogate tumor marker ${ }^{38}$-reached $1000 \mathrm{pg} /$ $\mathrm{mL}$, mice were treated with a single dose of MS IL$15_{50}$, , every week $\times 4$ anti-CCR4, or the combination of MS IL- $15_{50}$ pg with every week $\times 4$ anti-CCR4 (figure $8 \mathrm{~A}$ ). We confirmed the expression of CCR4 and CD25 on the MET-1 leukemia cells (figure 8B). Treatment with MS IL-15 $5_{50 \mu}$ markedly increased the NKp46 cells in blood compared with the phosphate-buffered saline

A

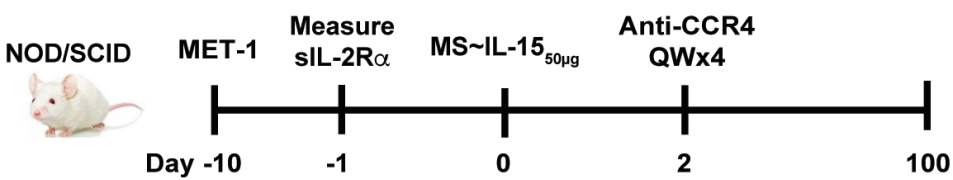

B

MET-1 tumor
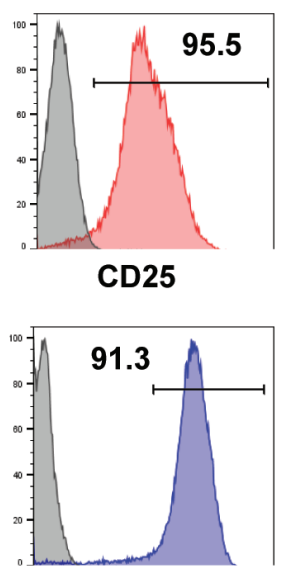

CCR4
C

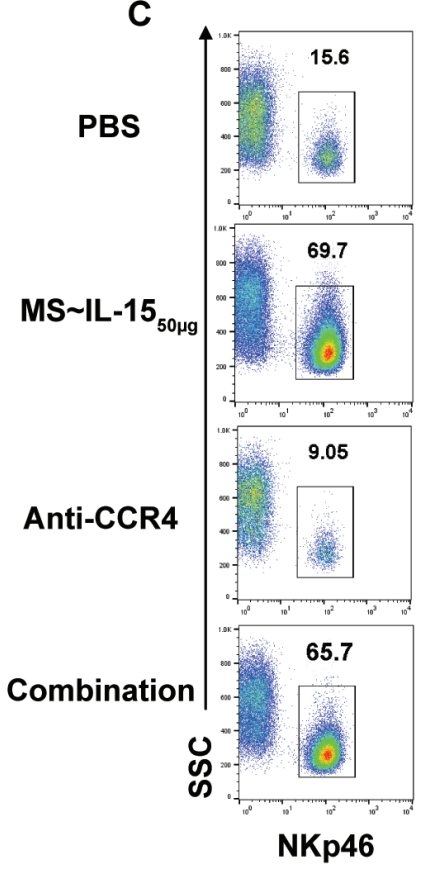

D

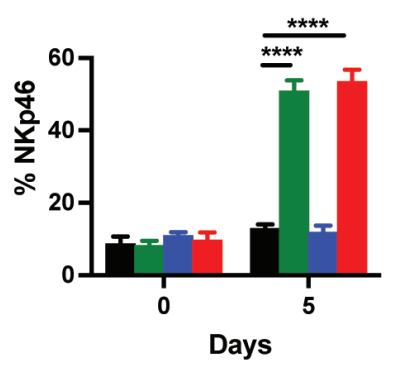

$\mathbf{F}$
E
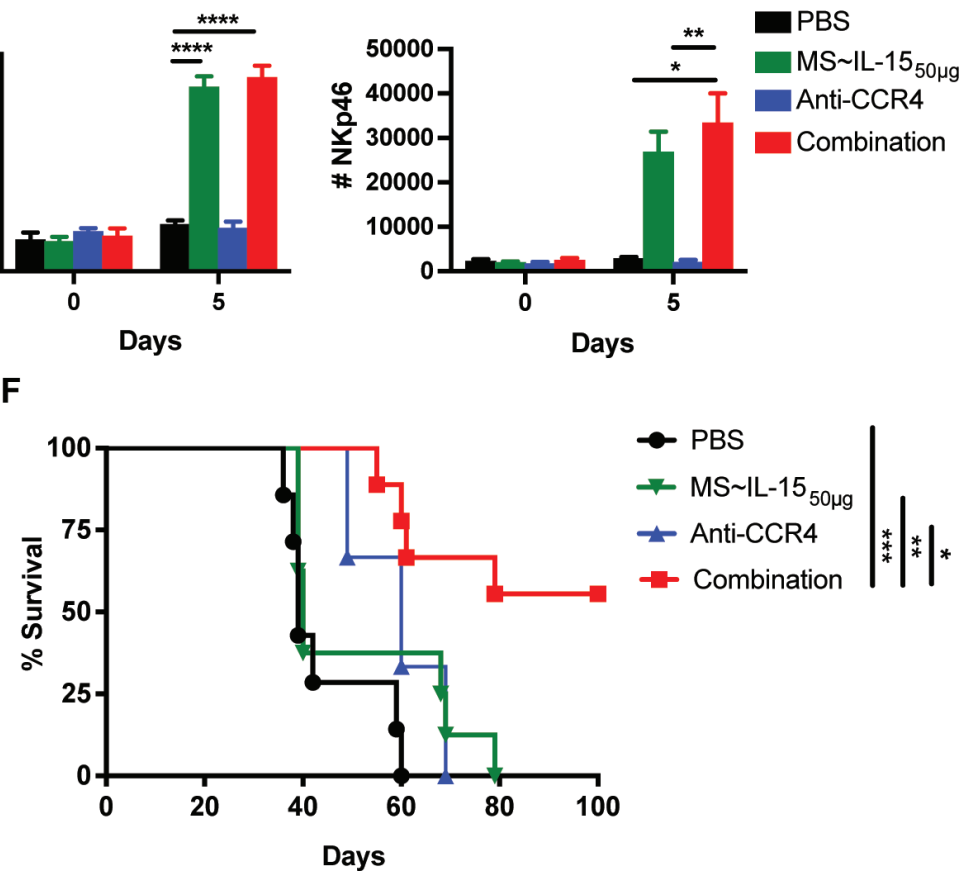

Figure 8 Treatment of MET-1-bearing NOD/SCID mice with MS IL-15 $5_{50}$ and anti-CCR4 antibody. (A) Experimental scheme of the xenograft model of human MET-1 leukemia. Ten days after intraperitoneal injection of leukemia cells $\left(2 \times 10^{7}\right.$ MET- 1 cells) in NOD/SCID mice ( $\mathrm{n}=3$ for anti-CCR4 to 9/group), animals were treated with PBS or subcutaneous MS IL-15 ${ }_{50}$; ; after 2 days, $100 \mu \mathrm{g}$ of CCR4 antibody was given intraperitoneally QWk×4. (B) Expression of CD25 and CCR4 on MET-1 tumor. (C) Representative flow cytometric analysis of NKp46 in blood on day 5 after MS IL-15 injection. (D-E) NKp46 cells in blood on day 5. (F) Kaplan-Meier curves illustrating the survival of mice that received PBS, MS IL-15 ${ }_{50}$, anti-CCR4, or the combination of MS IL-15 $5_{50 \mathrm{\mu g}}$ and anti-CCR4. The survival of the mice was recorded until day 100 post-therapy. Two-way analysis of variance and log-rank (Mantel-Cox) tests were used to determine statistical differences. ${ }^{*} \mathrm{P}<0.05,{ }^{* *} \mathrm{p}<0.01,{ }^{* \star *} \mathrm{p}<0.001,{ }^{* \star * \star} \mathrm{p}<0.0001$. IL, interleukin; IT, MS, microspheres; NK, natural killer; PBS, phosphate-buffered saline; QWk, every week. 
and anti-CCR4 groups (figure 8C-E). At 100-day posttreatments, $50 \%$ of the mice receiving combination of MS IL-15 $5_{50}$ and anti-CCR4 survived, whereas all others expired (figure 8F). Hence, the combination of MS-IL-15 and anti-CCR4 was highly effective at prolonging the survival of mice-bearing MET-1 leukemia.

\section{DISCUSSION}

Since the discovery of IL-15 in $1994,{ }^{39} 40$ extensive efforts have been expended toward its development as an immuno-oncology agent. ${ }^{23}$ Foremost in achieving this goal have been endeavors to control the effects of IL-15 on NK and $\mathrm{CD}^{+} \mathrm{T}$ cells, which link the cytokine to its therapeutic effects. More recently, the effects of IL-15 on $\gamma \delta$ $\mathrm{T}$ cells have received much interest because of their dual effects on both innate and adaptive immune responses, and potential importance in cancer immunotherapy. ${ }^{414}$ Optimal immune cell expansion requires IL-15 exposure at a level above a threshold concentration for a protracted period-a critical time-over-target. ${ }^{10-12}$ Since lower concentrations or times are not optimally efficacious, and higher concentrations or times may contribute to toxicities, an appropriate balance of agonist level and duration of exposure is essential. A major impediment to the success of IL-15 as an immunotherapeutic is that it has a short in vivo half-life of only 2.5 hours in the human; the high dose of a single injection necessary to achieve sufficient sustained exposure is accompanied by a high $\mathrm{C}_{\max }$ and associated toxicities. ${ }^{13}$ Hence, extensive efforts have been directed toward developing long-acting IL-15 agonists that remain within a narrow therapeutic window for long periods and achieve an optimal time-over-target.

In one approach, IL-15 super-agonists have been developed that increase potency and extend $\mathrm{t}_{1 / 2}$ by incorporation of IL-15R $\alpha$ and, in some cases, an Fc fragment-those in current clinical development include N-803, hetIL-15, and RLI. ${ }^{14}$ When administered intravenously to humans, these super-agonists have elimination $\mathrm{t}_{1 / 2} \mathrm{~s}$ of $\sim 1.5$ to 7.5 hours, which are not significantly different than the $2.5 \mathrm{~h} \mathrm{t}_{1 / 2}$ of intravenously administered IL-15. However, when administered subcutaneously, the effective $\mathrm{t}_{1 / 2} \mathrm{~s}$ are modestly increased to 4-24hours because of slow absorption from their injection sites. ${ }^{31} 4344$ In addition to slow absorption, some of the larger super-agonists are also poorly absorbed resulting in very low and potentially problematic bioavailability. For example, subcutaneously administered N-803-a large IL-15R $\alpha$-Fc complex with IL-15 N72D—has only 3\% bioavailability which indicates that $97 \%$ of the agonist is disposed of at the injection site; the high residual IL-15 activity may recruit immune cells that cause the injection site rashes commonly seen with this agonist. ${ }^{43}$ Although IL-15 has been attached to other long-lived Fc or IgG fragments, longer-acting agonists have not materialized. ${ }^{14}$ In another approach, high MW PEG has been attached to IL-15 to provide NKTR-255 which when administered intravenously to humans gave a $\mathrm{t}_{1 / 2}$ of $\sim 24$ hours $^{45}$; this makes NKTR-255 one of the IL-15 agonist front-runners, but the $\mathrm{t}_{1 / 2}$ is far from what is often achievable by PEGylation. In an alternative tactic, IL-2 has been PEGylated-for example, bempegaldesleukin and THOR-707-to bias binding toward IL-2R $\beta / \gamma_{c}$ such that the effects on immune cells mimic those of IL- $15^{46}$; these agonists also have modest $t_{1 / 2}$ values of $\sim 12$ hours. Finally, the most effective approach to maintain optimal levels of IL-15 over time has been to administer IL-15 via 5-day or 10-day $\mathrm{CIV}$, which show remarkable increases of $\mathrm{CD} 8^{+} \mathrm{T}$ cells, NK cells, and CD56 $6^{\text {bright }} \mathrm{NK}$ cells as well as impressive expansion of $\gamma \delta$ T cells. ${ }^{15}{ }^{16}$ However, CIV administration is a generally unacceptable and impractical mode of administration.

The primary objective of the present work was to develop a subcutaneously administered long-acting IL-15 that would, insofar as possible, mimic the PK of CIV and expand target immune cells levels over an extended period. We first prepared and characterized hydrogel MS covalently attached to the N-terminus of IL-15 by a $\beta$-eliminative linker that slowly releases the agonist. We then studied the PKs of subcutaneously administered MS IL-15 as well as its effect on expansion of target NK and $\mathrm{CD} 8^{+}$ $\mathrm{T}$ cells. Lastly, we demonstrated that a single dose of MS IL-15 is extremely effective in immunotherapy of cancer in both $\mathrm{NK}$ and $\mathrm{CD} 8^{+} \mathrm{T}$ cell-driven murine tumor models. Thus, with MS IL-15 we have developed a slow releasing depot of IL-15 which after a single subcutaneous injection causes an effective and persistent increase of NK and $\mathrm{CD} 44^{\text {hi }} \mathrm{CD}^{+} \mathrm{T}$ cells and high activity as an immunotherapeutic agent.

To prepare MS IL-15, we first attached an azido-linkeraldehyde to the N-terminus of IL-15 by reductive amination using a stoichiometry that favors mono-alkylation versus multi-alkylation. Then, we attached the azido-linker-IL-15 to cyclooctyne-activated MS by strain-promoted azidealkyne cycloaddition. The IL-15 in the MS IL-15 depots exceeded $95 \%$ purity and was stable under physiological and storage conditions for prolonged periods. On $\beta$-eliminative cleavage of the linker, IL- $15_{\mathrm{AP}}$ is released from the MS IL-15, which was equipotent to IL-15 in a cell-based IL-2R $\beta / \gamma$ c dimerization assay.

On subcutaneous administration of MS IL-15 containing $50 \mu \mathrm{g}$ of IL-15 (MS IL-15 $5_{50 \mu \mathrm{gg}}$ ) to mice, the released IL-15 $5_{\mathrm{AP}}$ maintained the $\sim 200$ to $300 \mathrm{pM}$ plasma concentration of IL-15 effective in CIV $^{16} 29$ with a $t_{1 / 2}$ of about 1 week for 5 days-far longer than any IL-15 agonist thus far reported. ${ }^{14}$ It was serendipitous that the 5-day duration of high exposure of the released agonist was a similar duration as that of the 5-day CIV we sought to emulate. ${ }^{15}$ Interestingly, after $\sim 5$ days there was an abrupt decrease in $\mathrm{t}_{1 / 2}$ to about $\sim 30$ hours, which was maintained for a several week period. The biphasic PKs were not observed in immune-deficient NSG mice and we did not detect anti-IL-15 antibodies that might increase CL. Similar time-dependent increases in CL observed with the super-agonist hetIL- $15^{31}$ and CIV infusion of IL-1 $5^{1629}$ have been attributed to formation of a dynamic IL-15 sink that consumes the cytokine, and the present study supports this hypothesis. 
Most reported studies of IL-15 in mice use a paucity of measurements over time to quantitate expansion of immune cells. We measured target immune cell expansion in spleen, lymph nodes, and PBMCs over a 28-day period which-although tedious-covers the complete duration of immune cell expansion observed with MS IL$15_{50} \mathrm{\mu g}$. To quantify proliferation and expansion, we developed an approach that measures the duration and extent that cells remained over controls. Here, we quantified the AUC of cell expansion over the 28-day study period, which is analogous to that commonly used in pharmacology to measure drug exposure over time. This approach allowed us to quantitatively compare long duration PD effects elicited by MS IL-15 that would be difficult to accomplish by conventional methods. We showed that $\mathrm{AUC}_{28 \mathrm{~d}}$ correlated well among tissues examined, and that MS IL-15 elicits very prolonged and very robust PD effects on its target immune cells. Hence, measurements of $\mathrm{AUC}_{28 \mathrm{~d}}$ provides compelling benefits over other approaches for quantitation of immune cell expansion by long-acting IL-15 agonists.

A single dose of MS IL- $15_{50}$ g resulted in protracted cell expansion of $\sim 14$ days for $\mathrm{NK}, \mathrm{CD}^{+}$, and $\mathrm{y} \delta \mathrm{T}$ cells, and a very long 28 days for $\mathrm{CD} 44^{\text {hi }} \mathrm{CD}^{+} \mathrm{T}$ cells. Indeed, the duration and expansion of immune cells elicited by MS $\sim \mathrm{IL}-15_{50 \mu \mathrm{g}}$ far exceeded alternative dose-equivalent administrations of free IL-15. For example, the PD effects of MS IL- $15_{50 \mu \mathrm{\mu g}}$ greatly surpassed those from a single dose of $25 \mu \mathrm{g} \mathrm{IL}-15-$ the estimated amount of IL- $15_{\mathrm{AP}}$ released from MS IL- $15_{50 \mu g}$ over 5 days-as well as $50 \mu \mathrm{g}$ IL-15the total amount of IL-15 present on MS IL- $15_{50 \mu \mathrm{\mu g}}$. Also, the average $\mathrm{AUC}_{28 \mathrm{~d}}$ values of proliferation and expansion of immune cells by MS IL- $15_{50 \mu g}$ exceeded those from five daily injections of $5 \mu \mathrm{g}$ IL- 15 by $\sim 150 \%$. Interestingly, $\mathrm{MS}_{\mathrm{GD}}$ $\mathrm{M}^{\sim}$ IL-15 $5_{50 \mathrm{\mu g}}$ with a monophasic $\mathrm{t}_{1 / 2}$ of $50 \mathrm{hr}$ showed similar PD effects as the longer acting MS IL- $15_{50} \mathrm{\mu g}$ and may represent the minimal exposure time of IL-15 to provide an optimal PD effect. Hence, compared with various dose-equivalent schedules of IL-15, MS IL-15 conjugates provide remarkably long and intense PD effects.

We also determined $\mathrm{AUC}_{28 \mathrm{~d}}$ of immune cell expansion after injections of varying amounts and frequencies of IL-15 and the super-agonist RLI. The $\mathrm{AUC}_{28 \mathrm{~d}}$ of immune cell expansion after single doses of varying amounts of IL-15 did not increase linearly as expected if expansion was directly related to dose and $\mathrm{C}_{\max }$. Rather, proliferation and expansion of NK and $\mathrm{CD} 44^{\text {max }} \mathrm{CD} 8^{+} \mathrm{T}$ cells increased logarithmically with dosage, indicating that increasing doses affected the time over which the cytokine remained at a concentration needed for receptor occupancy and activation. With the super-agonist RLI-which has a higher affinity for IL-2R $\beta / \gamma c$ receptor and longer $t_{1 / 2}$ than IL-15-two doses of only $2 \mu \mathrm{g}$ separated by 2 daysequimolar to only $1.2 \mu \mathrm{g}$ IL- $15 \times 2$-produced expansions superior to a single dose of $10 \mu \mathrm{g}$ RLI or $50 \mu \mathrm{g}$ IL- 15 . Finally, the dose-linear $\mathrm{AUC}_{28 \mathrm{~d}}$ of immune cell expansion after sequential single doses of $5 \mu \mathrm{g}$ IL-15 was also consistent with linearly increasing the time of exposure. Taken together, these data show that the PD effects of different doses of IL-15 are not directly correlated with $\mathrm{C}_{\text {max }}$, but rather with the time receptors are occupied with sufficient IL-15 to expand immune cells. Hence, the necessary timeover-target for optimal expansion cannot be achieved by single doses of IL-15 because of its short $t_{1 / 2}$, but can by multiple sequential doses or by the slow, steady release of IL-15 from a single subcutaneous administration of longacting MS IL-15 $5_{50 \mathrm{\mu g}}$.

These results all support the view that optimal in vivo proliferation of immune cells requires IL-15 exposure at a level above some minimal threshold concentration for some minimal period of time. However, cytokine stimulation that is too sustained or too frequent may be detrimental to immune cell expansion or function, ${ }^{334748}$ and the optimal in vivo exposure time or level is yet to be determined. For example, Elpek et $a t^{47}$ found that transient treatment of mice with potent IL-15/IL-15R $\alpha$ complexes increased the number and effector functions of activated NK cells, whereas prolonged stimulation led to accumulation of mature NK cells with impaired function. Likewise, Frutoso $e t a l^{33}$ reported NK cell hyporesponsiveness to IL-15 agonists in mice whereby a second dose administered as long as 50 days after the first resulted in a large attenuation in NK-cell proliferation. On a second treatment of mice with MS IL-15 1 month after the first, we also observed NK cell hyporesponsiveness. However, there are substantial interspecies differences in NK cell subsets and cell surface receptors in mice and humans, so the IL-15-induced NK hyporesponsiveness in mice need not translate to humans. ${ }^{49}{ }^{50}$ Indeed, in non-human primates and humans immune cell responsiveness and effector functions do not appear significantly impaired after multiple doses of N-803, ${ }^{43}{ }^{51}$ RLI,${ }^{44}$ NKTR-255, ${ }^{45}$ or by CIV IL-15, ${ }^{151629}$ especially if a suitable rest interval is allowed between doses or treatment cycles. In view of the apparent species differences of NK cell hyporesponsiveness and exhaustion, we did not consider it necessary to resolve these issues in mice and did not pursue further studies of multiple doses of MS IL-15.

Finally, MS IL-15 was assessed as an immunotherapeutic agent in two murine tumor models. First, it was tested in combination with IT-administered agonistic anti-CD40 in a bilateral TRAMP-C2 model of prostatic cancer (Chen, submitted), primarily driven by cytotoxic $\mathrm{CD}^{+} \mathrm{T}$ cells. ${ }^{24} \mathrm{~A}$ single subcutaneous injection of MS IL$15_{50 \mathrm{\mu g}}$ and IT CD40 agonist in one of the tumors showed modest growth inhibition when individually administered, but evoked robust antitumor activity in both tumors when administered as a combination. Second, in the MET-1 model of ATL, ${ }^{26}$ driven by NK cells, a single dose of MS IL- $15_{50}$ pg caused a very large expansion of NK cells. Single-agent MS IL-15 $5_{50}$ pg or anti-CCR4 provided modest increases in survival, but a combination of both significantly prolonged survival. Clearly, MS IL-15 should be pursued as an immunotherapeutic agent in human cancers, especially in combination with other agents that may be synergistic with the cytokine. 
In summary, the MS IL-15 prodrug provides a very longacting IL-15-longer than any known IL-15 agonist-and the PD effects are likewise longer lasting than any IL-15 agonist yet reported. The IL-15 released from the MS has a low $\mathrm{C}_{\text {max }}$ and causes protracted high expansion of NK cells and $\gamma \delta$ and $\mathrm{CD} 44^{\text {hi }} \mathrm{CD} 8^{+} \mathrm{T}$ cells. MS IL-15 shows robust anticancer activity in NK and cytotoxic $\mathrm{CD}^{+} \mathrm{T}$ celldriven responses, especially when administered in combination with other immunotherapeutic agents. From our perspective, important future work entails studies of MS IL-15 in non-human primates and then in human clinical trials. Also, further studies on the MS delivery system should address (a) determining the optimal $t_{1 / 2}$ of IL-15 release from the depot-sufficient but not excessive to produce optimal PD effects, (b) investigating the effects of an MS prodrug of a more potent, longer-acting super-agonist, such as the IL-15Ro-independent agonist RLI, and (c) applying the technology to other cytokines that could benefit from half-life extension. Since the PKs of MS IL-15 are largely due to the nature of the $\beta$-eliminative linker connecting IL-15 to the carrier, and the rate of release is species-independent, we are optimistic that results obtained here will translate from mouse to man.

Acknowledgements The authors would like to dedicate this manuscript to Dr Thomas Waldmann. The authors would like to thank Drs Christopher Carreras, Hongruo Yun, Shaun Fontaine, Jeff Henise, Rocio Fernandez, and Guillermo Hails for technical assistance, Dr Bora Han for advising on the toxicology study, and Dr Gary Ashley for insightful discussions.

Contributors Conceptualization: DVS, TAW. Investigation: JAH, WC, SPD, AD, JRM, RR. Supervision: DVS, TAW. Writing: DVS, TAW, JAH. WC, SPD, and AD contributed equally. Guarantor: DVS.

Funding Some flow cytometry data reported was collected at the UCSF Helen Diller Family Comprehensive Cancer Center Lab for Cell Analysis, which is supported by the National Cancer Institute of the National Institutes of Health under Award Number P30CA082103.

Disclaimer The content is solely the responsibility of the authors and does not necessarily represent the official views of the National Institutes of Health.

Competing interests JAH, RR, and DVS are employees and hold options or stock in ProLynx Inc. All other authors declare that they have no competing interests.

Patient consent for publication Not applicable.

Ethics approval Animal experiments performed at the $\mathrm{NIH} / \mathrm{NCl}$ were approved by the $\mathrm{NCl}$ Animal Care and Use Committee and were performed in accordance with $\mathrm{NCl}$ Animal Care and Use Committee guidelines. All other animal handling and care was performed by MuriGenics (Vallejo, California) and Explora Biolabs (San Francisco, California) and conformed to IACUC recommendations.

Provenance and peer review Not commissioned; externally peer reviewed.

Data availability statement All data relevant to the study are included in the article or uploaded as supplementary information.

Supplemental material This content has been supplied by the author(s). It has not been vetted by BMJ Publishing Group Limited (BMJ) and may not have been peer-reviewed. Any opinions or recommendations discussed are solely those of the author(s) and are not endorsed by BMJ. BMJ disclaims all liability and responsibility arising from any reliance placed on the content. Where the content includes any translated material, BMJ does not warrant the accuracy and reliability of the translations (including but not limited to local regulations, clinical guidelines, terminology, drug names and drug dosages), and is not responsible for any error and/or omissions arising from translation and adaptation or otherwise.

Open access This is an open access article distributed in accordance with the Creative Commons Attribution Non Commercial (CC BY-NC 4.0) license, which permits others to distribute, remix, adapt, build upon this work non-commercially, and license their derivative works on different terms, provided the original work is properly cited, appropriate credit is given, any changes made indicated, and the use is non-commercial. See http://creativecommons.org/licenses/by-nc/4.0/.

\section{ORCID iDs}

John A Hangasky http://orcid.org/0000-0002-8386-3922

Thomas A Waldmann http://orcid.org/0000-0003-4500-6660

\section{REFERENCES}

1 Robinson TO, Schluns KS. The potential and promise of IL-15 in immuno-oncogenic therapies. Immunol Lett 2017;190:159-68.

2 Waldmann TA, Miljkovic MD, Conlon KC. Interleukin-15 (dys) regulation of lymphoid homeostasis: Implications for therapy of autoimmunity and cancer. J Exp Med 2020;217:e20191062.

3 Waldmann TA, Dubois S, Miljkovic MD, et al. IL-15 in the combination immunotherapy of cancer. Front Immunol 2020;11:868.

4 Bergamaschi C, Stravokefalou V, Stellas D, et al. Heterodimeric IL-15 in cancer immunotherapy. Cancers 2021;13:837.

5 Fiore PF, Di Matteo S, Tumino N, et al. Interleukin-15 and cancer: some solved and many unsolved questions. $J$ Immunother Cancer 2020;8:e001428.

6 Waldmann TA. The biology of interleukin-2 and interleukin-15: implications for cancer therapy and vaccine design. Nat Rev Immunol 2006;6:595-601.

7 Dubois S, Mariner J, Waldmann TA, et al. IL-15R alpha recycles and presents IL-15 in trans to neighboring cells. Immunity 2002;17:537-47.

8 Giron-Michel J, Giuliani M, Fogli M, et al. Membrane-bound and soluble IL-15/IL-15Ralpha complexes display differential signaling and functions on human hematopoietic progenitors. Blood 2005;106:2302-10.

9 Marks-Konczalik J, Dubois S, Losi JM, et al. IL-2-induced activationinduced cell death is inhibited in IL-15 transgenic mice. Proc Natl Acad Sci U S A 2000;97:11445-50.

10 Judge AD, Zhang X, Fujii $H$, et al. Interleukin 15 controls both proliferation and survival of a subset of memory-phenotype CD8(+) T cells. J Exp Med 2002;196:935-46.

11 Berard M, Brandt K, Bulfone-Paus S, et al. IL-15 promotes the survival of naive and memory phenotype CD8+ T cells. J Immunol 2003;170:5018-26.

12 Zhao YM, French AR. Mechanistic model of natural killer cell proliferative response to IL-15 receptor stimulation. PLOS Comput Biol 2013;9:e1003222.

13 Conlon KC, Lugli E, Welles HC, et al. Redistribution, hyperproliferation, activation of natural killer cells and CD8 T cells, and cytokine production during first-in-human clinical trial of recombinant human interleukin-15 in patients with cancer. J Clin Oncol 2015;33:74-82.

14 Hangasky JA, Waldmann TA, Santi DV. Interleukin 15 pharmacokinetics and consumption by a dynamic cytokine sink. Front Immunol 2020;11:11.

15 Dubois SP, Miljkovic MD, Fleisher TA, et al. Short-course IL-15 given as a continuous infusion led to a massive expansion of effective NK cells: implications for combination therapy with antitumor antibodies. $J$ Immunother Cancer 2021;9:e002193.

16 Conlon KC, Potter EL, Pittaluga S, et al. IL15 by continuous intravenous infusion to adult patients with solid tumors in a phase I trial induced dramatic NK-cell subset expansion. Clin Cancer Res 2019;25:4945-54.

17 Santi DV, Schneider EL, Reid R, et al. Predictable and tunable half-life extension of therapeutic agents by controlled chemical release from macromolecular conjugates. Proc Natl Acad Sci U S A 2012;109:6211-6.

18 Henise J, Hearn BR, Ashley GW, et al. Biodegradable tetraPEG hydrogels as carriers for a releasable drug delivery system. Bioconjug Chem 2015;26:270-8.

19 Henise J, Yao B, Ashley GW, et al. Autoclave sterilization of tetra-polyethylene glycol hydrogel biomaterials with $\beta$-eliminative crosslinks. Engineering Reports 2020;2:e12091.

20 Henise J, Yao B, Hearn BR, et al. High-throughput, aseptic production of injectable Tetra-PEG hydrogel microspheres for delivery of releasable covalently bound drugs. Engineering Reports 2020;2:e12213

21 Henise J, Fontaine SD, Hearn BR, et al. In vitro-in vivo correlation for the degradation of tetra-PEG hydrogel microspheres with tunable $\beta$ -eliminative crosslink cleavage rates. Int J Polym Sci 2019;2019:1-7.

22 Mortier E, Quéméner A, Vusio P, et al. Soluble interleukin- 15 receptor alpha (IL-15R alpha)-sushi as a selective and potent agonist of IL-15 
action through IL-15R beta/gamma. Hyperagonist IL-15 x IL-15R alpha fusion proteins. J Biol Chem 2006;281:1612-9.

23 Schneider EL, Hearn BR, Pfaff SJ, et al. Approach for half-life extension of small antibody fragments that does not affect tissue uptake. Bioconjug Chem 2016;27:2534-9.

24 Zhang M, Ju W, Yao Z, et al. Augmented IL-15R $\alpha$ expression by CD40 activation is critical in synergistic CD8 T cell-mediated antitumor activity of anti-CD40 antibody with IL-15 in TRAMP-C2 tumors in mice. J Immunol 2012;188:6156-64.

25 Phillips KE, Herring B, Wilson LA, et al. IL-2Ralpha-directed monoclonal antibodies provide effective therapy in a murine model of adult T-cell leukemia by a mechanism other than blockade of IL-2/ IL-2Ralpha interaction. Cancer Res 2000;60:6977-84.

26 Zhang M, Wen B, Anton OM, et al. IL-15 enhanced antibodydependent cellular cytotoxicity mediated by NK cells and macrophages. Proc Natl Acad Sci U S A 2018;115:E10915-24.

27 Nellis DF, Michiel DF, Jiang M-S, et al. Characterization of recombinant human IL-15 deamidation and its practical elimination through substitution of asparagine 77. Pharm Res 2012;29:722-38.

28 Soman G, Yang X, Jiang H, et al. MTS dye based colorimetric CTLL-2 cell proliferation assay for product release and stability monitoring of interleukin-15: assay qualification, standardization and statistical analysis. J Immunol Methods 2009;348:83-94.

29 Sneller MC, Kopp WC, Engelke KJ, et al. IL-15 administered by continuous infusion to rhesus macaques induces massive expansion of CD8+ T effector memory population in peripheral blood. Blood 2011;118:6845-8.

30 Han K-ping, Zhu X, Liu B, et al. IL-15:IL-15 receptor alpha superagonist complex: high-level co-expression in recombinant mammalian cells, purification and characterization. Cytokine 2011:56:804-10.

31 Bergamaschi C, Watson DC, Valentin A, et al. Optimized administration of hetIL-15 expands lymphocytes and minimizes toxicity in rhesus macaques. Cytokine 2018;108:213-24.

32 Miyazaki T, Maiti M, Hennessy M, et al. NKTR-255, a novel polymerconjugated rhlL-15 with potent antitumor efficacy. J Immunother Cancer 2021;9:e002024.

33 Frutoso M, Morisseau S, Tamzalit F, et al. Emergence of NK cell hyporesponsiveness after two IL-15 stimulation cycles. J Immunol 2018;201:493-506.

34 Perdreau H, Mortier E, Bouchaud G, et al. Different dynamics of IL-15R activation following IL-15 cis- or trans-presentation. Eur Cytokine Netw 2010;21:29-307.

35 Bessard A, Solé V, Bouchaud G, et al. High antitumor activity of $\mathrm{RLI}$, an interleukin-15 (IL-15)-IL-15 receptor alpha fusion protein, in metastatic melanoma and colorectal cancer. Mol Cancer Ther 2009;8:2736-45.

36 Hearn BR, Fontaine SD, Schneider EL, et al. Attenuation of the reaction of Michael acceptors with biologically important nucleophiles. Bioconjug Chem 2021;32:794-800.

37 Ishida T, Utsunomiya A, lida S, et al. Clinical significance of CCR4 expression in adult T-cell leukemia/lymphoma: its close association with skin involvement and unfavorable outcome. Clin Cancer Res 2003;9:3625-34.

38 Tendler CL, Greenberg SJ, Blattner WA, et al. Transactivation of interleukin 2 and its receptor induces immune activation in human
T-cell lymphotropic virus type I-associated myelopathy: pathogenic implications and a rationale for immunotherapy. Proc Natl Acad Sci U $S$ A 1990;87:5218-22.

39 Burton JD, Bamford RN, Peters C, et al. A lymphokine, provisionally designated interleukin $\mathrm{T}$ and produced by a human adult T-cell leukemia line, stimulates T-cell proliferation and the induction of lymphokine-activated killer cells. Proc Natl Acad Sci U S A 1994;91:4935-9.

40 Grabstein KH, Eisenman J, Shanebeck K, et al. Cloning of a T cell growth factor that interacts with the beta chain of the interleukin-2 receptor. Science 1994;264:965-8.

41 Silva-Santos B, Serre K, Norell H. Gammadelta T cells in cancer. Nat Rev Immunol 2015;15:683-91.

42 Vantourout P, Hayday A. Six-of-the-best: unique contributions of $\gamma \delta$ T cells to immunology. Nat Rev Immunol 2013;13:88-100.

43 Romee R, Cooley S, Berrien-Elliott MM, et al. First-in-human phase 1 clinical study of the IL-15 superagonist complex ALT-803 to treat relapse after transplantation. Blood 2018;131:2515-27.

44 Podzimkova N, Adkins I, Martynoff Gde, et al. 563 Pharmacodynamics and pharmacokinetics of SO-C101 in cynomolgus monkeys. J Immunother Cancer 2020;8:A597.

45 Shah N, Tan A, Budde L, et al. 355 First-in-human phase I study of NKTR-255 in patients with relapsed/refractory hematologic malignancies. J Immunother Cancer 2020;8:A380.

46 Overwijk WW, Tagliaferri MA, Zalevsky J. Engineering IL-2 to give new life to T cell immunotherapy. Annu Rev Med 2021;72:281-311.

47 Elpek KG, Rubinstein MP, Bellemare-Pelletier A, et al. Mature natural killer cells with phenotypic and functional alterations accumulate upon sustained stimulation with IL-15/IL-15Ralpha complexes. Proc Natl Acad Sci U S A 2010;107:21647-52.

48 Felices M, Lenvik AJ, McElmurry R, et al. Continuous treatment with IL-15 exhausts human NK cells via a metabolic defect. JCl Insight 2018;3:e96219.

49 Guillerey C, Huntington ND, Smyth MJ. Targeting natural killer cells in cancer immunotherapy. Nat Immunol 2016;17:1025-36.

50 Zamora AE, Grossenbacher SK, Aguilar EG. Models to study NK cell biology and possible clinical application. Curr Protoc Immunol 2015;110:14.37.1-14.

51 Webb GM, Molden J, Busman-Sahay K, et al. The human IL-15 superagonist $\mathrm{N}-803$ promotes migration of virus-specific CD8+ $T$ and NK cells to $B$ cell follicles but does not reverse latency in ART-suppressed, SHIV-infected macaques. PLoS Pathog 2020;16:e1008339.

52 Marabelle A, Champiat S, Garralda E, et al. 807 A multicenter open-label phase I/lb study of SO-C101 as monotherapy and in combination with pembrolizumab in patients with selected advanced/metastatic solid tumors. J Immunother Cancer 2020;8:A856

53 Chertova E, Bergamaschi C, Chertov O, et al. Characterization and favorable in vivo properties of heterodimeric soluble IL-15.IL15Ralpha cytokine compared to IL-15 monomer. J Biol Chem 2013;288:18093-103.

54 Liu B, Jones M, Kong L, et al. Evaluation of the biological activities of the IL-15 superagonist complex, ALT-803, following intravenous versus subcutaneous administration in murine models. Cytokine 2018;107:105-12. 